2E11 高血圧症家族歴有無による血中脂質、インスリン值の差異

○澳親人、平山純二、森恵子、黒山裕子、西浦正芳

(国保日高総合病院第二内科)

南條輝志男

(和歌山県立医科大学第一内科)

疫学、高血圧症家族歴、高インスリン血症

【目的】平成 5 年度に和歌山県印南町において HT\&HTFH群で最も高值の傾向にあった。

高血圧症 $(\mathrm{HT})$ と糖尿病 $(\mathrm{DM})$ との関連を調查し、 HT、HT家族歴共に有する群（HT\&HTFH群）で最 もDM有病率が高いことを見いだし、DMの危険因 子としてのHT家族歷の重要性を発表した。今回、 平成 6 年度検診結果を追加しHT\&HTFH群と脂質、 インスリン血症との関連性を検討した。

【対象および方法】対象は平成 5 年度と 6 年度 に続けて印南町住民健診を受診した1231名。DM の診断は1985年WH0の診断基準を、HTの診断は 1978年WH0診断基淮を用いた。家族歴の問診を 行い、空腹時生化学的検查を行うと共に、血清 インスリン (IRI)、Cペプチド (CPR) 值を測定し た。HT\&HTFH群のDM発症前の特質を見出すため、 DM未発症群においてHT, HT家族歴有無により対 象を 4 群に分け、血中脂質、BMI、血糖值、IRI、 CPRに差異があるか否かを検討した。有意差検 定はANOVAを用い、 $\mathrm{p}<0.05$ を有意とした。IRI、 CPRは正規分布にするため、対数変換を行った 後に検討した。

【結果】DM未発症群を対象とし、まずHTの有無 により各種指標の差異を検討したところ、総コ レステロール、中性脂肪、BMI、血糖值、IRI、 CPRはHT有り群で有意 $(\mathrm{p}<0.01)$ に高值であり、 HDL コレステロール、IRI/CPRモル比には有意な 差異がみられなかった。HT有無で有意差がみら れた各指標について、さらにHT家族歴の有無を も含めて 4 群に分けて検討したところ、総コレ ステロール、BMI、CPRはHT\&HTFH群で最も高値 であった $(\mathrm{p}<0.05)$ 。中性脂肪、血糖値、IRIも
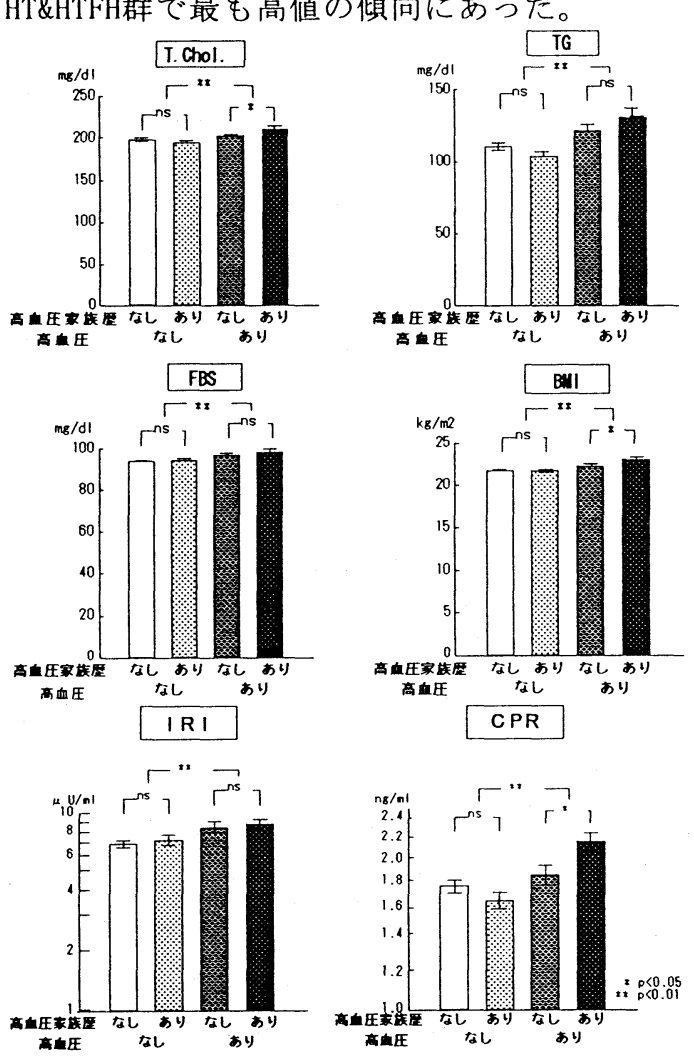

【考察】糖尿病未発症群における検討で、HT 群では血中脂質、血糖值、BMI、IRI、CPRも有 意な高值あり、HT家族歴をも有する群 (HT\&HTFH 群)では最も高值であった。糖疗病有病率が最 も高いHT\&HTFH群においては、DM未発症にもか かわらず高脂血症、肥満、高血糖、高脂血症、 高インスリン血症が最も顕著に認められたこ とは、高血圧の遺伝的素因とインスリン抵抗性 症候群との関連性を検討する上で興味ある知 見と思われる。 
2E12 インスリン非依存型糖尿病におけるミクロアルブミン尿と血中アンジオテン シン変換醳素活性との関係

○和田克哉、白石幸雄、久保敬二、蔵本淳、高科成良 （広島県農村医学研究所）

糖尿病、ミクロアルブミン尿、アンジオテンシン変換酵素

【はじめに】

ミクロアルブミン尿は、糖尿病性腎症の早 期マーカーであり、MAU陽性の糖尿病患者で は陰性の患者に比し血圧が高いとの報告があ る。また、糖尿病では腎内レニン・アンジオ テンシン系が亢進している。本研究では、血 中アンジオテンシン変換酵素活性(ACE)を測 定し、インスリン非依存型糖尿病(NIDDM)に おけるミクロアルブミン尿とレニン・アンジ オテンシン系との関係の一端を明らかにす る。

\section{【対象と方法】}

対象は教育入院中の高血圧症、及び顕性蛋 白尿を有しないNIDDM患者で、入院時連続3 日間の24時間蓄尿中アルブミン排泄量によ り、ミクロアルブミン尿陰性のA群（ 15 $\mathrm{mg} / \mathrm{g}$ Cre $) 17$ 名亡陽性のB群( >15 mg/g Cre)18名に分類した。約2週間の血糖コント ロール前後でACE活性を測定した。危険率が 0.05より小さいとき、有意な差があると判 定した。

\section{【成績並びに考察】}

（1）血糖コントロール前後で、早朝空腹時の 収縮期及び拡張期血圧、ACE活性、stable

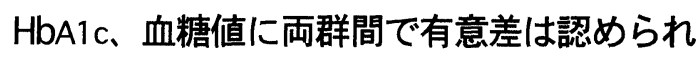
ず、また、両群それぞれにおいてアルブミン 排泄量と各血圧、あるいはACE活性との相関 関係に有意性は見られなかった。（2）ミクロ
アルブミン尿陰性群において、血糖コントロ 一ル前、ACE活性はstable HbA1c、及び拡張 期血圧と有意な正相関関係を示したが、陽性 群では相関は認められなかった。これより、 NIDDMにおいて血糖コントロール不良の程度 に比例してACE活性が増大しており、それに 応じて拡張期血圧が上昇する機序をミクロア ルブミン尿は障害する可能性が考えられた。 （3）ミクロアルブミン尿陰性群において、血 糖コントロール改善によるACE活性の変化量 は、コントロール前のstable HbA1c、及び コントロール前後の早朝空腹時血糖值の変化 量と有意な負の相関関係を示したが、陽性群 ではそのような関係は認められなかった。こ のことは、約2週間の血糖コントロール改善 による空腹時血糖值の低下の程度に比例して ACE活性が減少する機序をミクロアルブミン 尿か障害する可能性を示唆している。

\section{【結語】}

NIDDMにおけるミクロアルブミン尿の発症 は、血圧、及びACE活性レベルに直接影響し ないが、血糖コントロール不良による血糖值 上昇がACE活性の増大を誘起し、拡張期血圧 を上昇させる機序を修飾することが示唆され た。 
2E13 75gOGTTによる糖尿病発症予防の新たな指標設定の試み

広島農村医学研究所

○石田和史、久保敬二、関口善孝、高科成良

糖尿病、75gOGTT、移行率

【目的】75gOGTTを用い、糖尿病発症予防 のための有力な新指標が設定できるか否か を検討する。

【対象および方法】対象は、当施設で管理 した75gOGTTを含む成人病検診の受診者の うち、初回受診時に糖尿病と判定されなか った3129例である。各対象を1〜12年(平均 観察期間4.1年)観察し、観察期間中正常 型・境界型から糖尿病に移行しなかった群 (G1)、IGTから糖尿病に移行しなかった群 (G2)、正常型・境界型より糖尿病に移行し た群(G3)、IGTより糖尿病に移行した群 (G4)の4群に分類し、各対象の初回受診時 の空腹時血糖 $(\mathrm{FPG}) 、 75 \mathrm{gOGTT} 1$ 時間値 (1HPG)、75gOGTT2時間值(2HPG)の值の それぞれ2乗、積および1HPGと2HPGの平 均值を算出して新たな指標の候補とし、各 指標候補を100または1000階級に分割して、 対象者の分布および累積指数(\%)を求め、 G1とG3、G2とG4でそれぞれ比較検討し、 最適指標(その指標以上で糖尿病への移行率 が高く、かつ糖尿病に移行しない率が低い
指標)を検討した。

【成績】(1)G1とG3の比較での最適指標は $(1 \mathrm{HPG})^{2}$ の25000であり、この值以上では正 常型・境界型より糖尿病型へ移行した者の 81.1(=100-18.9)\%、移行しなかった者の 20.8(=100-79.2)\%が含まれた。(2)G2とG4の 比較での最適指標は $(1 \mathrm{HPG}) \times(2 \mathrm{HPG})$ の 34000であり、この值以上ではIGTより糖尿 病へ移行した者の69.4(=100-30.6)\%、移行 しなかった者の19.5(=100-80.5)\%が含まれ た。(表参照)

【結語】初診時の75gOGTTにおいて、正常 型あるいは境界型と判定された場合は OGTT1時間值の2乗值が25000以上で約 80\%、IGTと判定された場合はOGTT1時間 值と2時間値の積が34000以上で約70\%がそ の後の観察で糖尿病に移行したことが明ら かとなり、従来の指標に比較し、これらの 指標が検診での75gOGTTの結果から将来の 糖尿病の発症をより高率に予測しうる指標 であり、さらには糖尿病発症予防に極めて 有用と考えられる。

表 最適指標別累積指数（\%）の比較

\begin{tabular}{|c|c|c|c|c|c|c|}
\hline & 指標 & G1 & G3 & 指標 & G2 & G4 \\
\hline FPG $\times$ FPG & $<9000$ & $75.0 \%$ & $46.7 \%$ & $<11000$ & $86.2 \%$ & $58.7 \%$ \\
\hline 1HPG $\times 1 \mathrm{HPG}$ & $<25000$ & $992 \%$ & $18.9 \%$ & $<44000$ & $79.0 \%$ & $41.3 \%$ \\
\hline 2HPG $\times 2 \mathrm{HPG}$ & $<14000$ & $79.8 \%$ & $41.1 \%$ & $<28000$ & $81.3 \%$ & $39.7 \%$ \\
\hline FPG $1 \mathrm{HPG}$ & $<15000$ & $80.0 \%$ & $25.6 \%$ & $<21000$ & $82.5 \%$ & $41.3 \%$ \\
\hline FPG $\times 2 \mathrm{HPG}$ & $<11000$ & $81.3 \%$ & $37.8 \%$ & $<16000$ & $77.6 \%$ & $29.8 \%$ \\
\hline $1 \mathrm{HPG} \times 2 \mathrm{HPG}$ & $<18000$ & $80.4 \%$ & $22.2 \%$ & $<34000$ & $80.5 \%$ & $30.6 \%$ \\
\hline$(1 \mathrm{HPG}+2 \mathrm{HPG}) / 2$ & $<140$ & $84.1 \%$ & $26.7 \%$ & $<190$ & $84.0 \%$ & $39.7 \%$ \\
\hline
\end{tabular}

[註] $\mathrm{G} 1$ : 正常型・境界型 $\rightarrow$ 非糖尿病型 G3 : 正常型・境界型 $\rightarrow$ 糖尿病型 G2 : IGT $\rightarrow$ 非糖尿病 FPG : 空腹時血糖値 $1 \mathrm{HPG}: 75 \mathrm{gOGTT} 1$ 時間血糖值 $2 \mathrm{HPG}: 75 \mathrm{gOGTT} 2$ 時間血糖値 


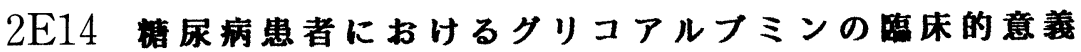

○深沢英雄、角田博信、平松武幸、新井晶勇己 山田茂夫、寺田龍也、池田哲朗、篠田嘉生

\section{(愛知・愛北病院)}

\section{グリコアルブミン、糖尿病}

【目的】糖尿病における血糖コントロール指 標として従来から $\mathrm{H} \mathrm{b} \mathrm{A} \mathrm{lc、フルクトサミン}$ (F R A )、1,5-AGが使われている。今 回、我々は新しい短期間の指標であるグリコ アルブミン（G A ）の臨床的意義を検討した。 【対象および方法】当院外来に通院中の糖尿 病患者 136 名を対象に血糖、H b A lc、F R A、G A、血清総蛋白（TP）を測定した。 同時に当院で透析中の糖尿病患者 32 名を対 象に、透析前後に同様の測定を行った。G A の測定は H P L C 法（京都第一科学）を使用 した。

【成績】1.外来患者におけるGAとFRA、 H b A 1c 糖尿病患者で G A と F R A 相関 は $\mathrm{r}=0.860 、 \mathrm{GA}$ と $\mathrm{H} \mathrm{b} \mathrm{A} \mathrm{lc}$ は $\mathrm{r}=0$. 837 と A F F Aにより近い相関を示し た（図 1)。2，透析糖尿病患者でのGAと TP、FRA TPとFRAの相関は $\mathrm{r}=0$. $514 、 \mathrm{TP}$ と $\mathrm{G}$ は $\mathrm{r}=0.094$ と、 $\mathrm{F}$ $\mathrm{R} A$ は透析後 T P の上昇と平行する傾向が見 られたが、GAにはその様な傾向は認められ なかった（図2）。

【結論】1. G A \& F R と同様、短期間の 血糖コントロールを反映している。2，G A はF RAに比べT P の影響を受けにくいと考 えられた。3. 以上、糖尿病患者のコントロ 一ル改善の指標としてのGAは従来用いられ てきた指標に比し特に差はないが、病態によ っては有用と思われた。
図1 グリコアルブミンとフルクトサミンの相関 （外来糖尿病患者）

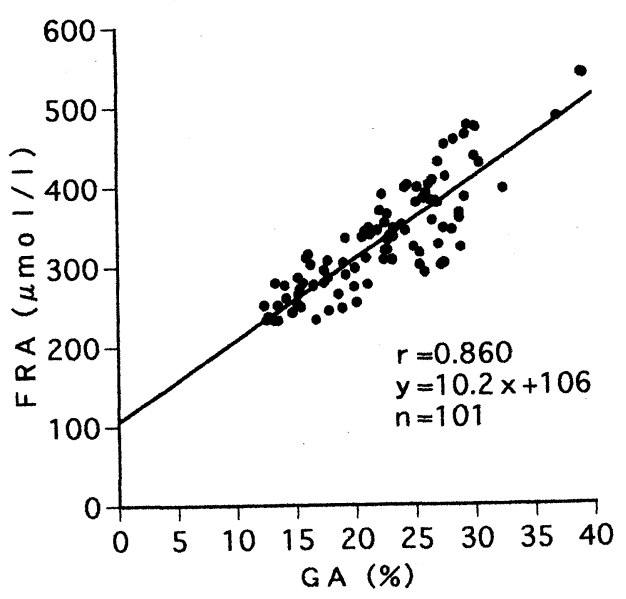

図2 グリコアルフミンと血清総蛋白の相関 （糖尿病患者、透析後）

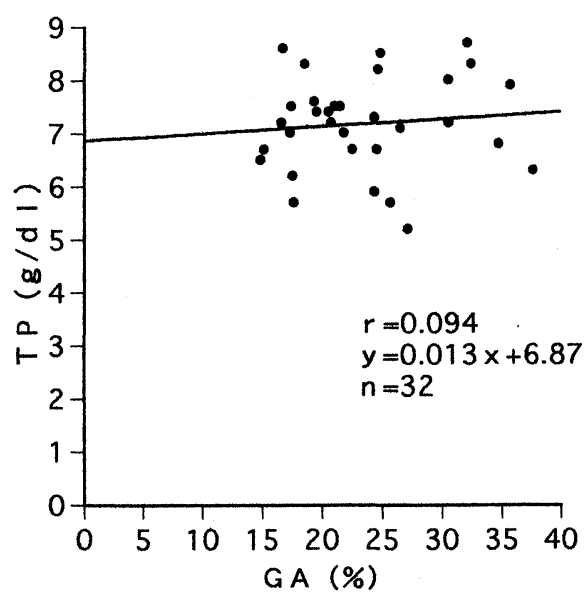


2E15 NIDDM 患者における $\alpha-$ Gl ucosi dase Inhibi tor の使用経験

広島県厚生連廣島総合病院 内科

○久保 敬二 石田 和史 関口 善孝 蔵本 淳 高科成良

\section{インスリン非依存糖尿病 $\alpha$-Glucosidase Inhibitor インスリン抵抗性}

(目的)

インスリン非依存糖尿病（NIDDM）患者 に $\alpha$-Glucosidase Inhibitor $(\alpha-\mathrm{Gl})$ を投 与し、血糖コントロール、脂質代謝、インス リン分泌能に及ぼす影響について検討した。 （対象および方法）

当院糖尿病外来通院中の NIDDM 患者 17 名を対象とした。 $\alpha$-GI である Acarbose $300 \mathrm{mg} /$ day を 6 力月間投与し、その前後 で、空腹時血糖（FPG）、HbA1C、Body Mass Index ( BMI) 、総コレステロール ( T. Chol )、中性脂肪 ( TG )、HDL-コレステロ ール ( HDL - Chol ) 、空腹時血清インスリン （F－IRI）を測定した。数值は平均値士標準 偏差で示し、平均値の比較には Paired $T$ Test を使用した。

（成績）

\section{（１）食事療法群での成績}

男性 1 名、女性 6 名の合計 7 名で、年齢 は $60.6 \pm 9.7$ 才であった。FPG は投与前 $163.7 \pm 18.0 \mathrm{mg} / \mathrm{dl}$ に対し、投与後は $154.7 \pm 19.2 \mathrm{mg} / \mathrm{dl}$ で投与前後で変化し なかった。HbA1C は投与前の $7.9 \pm 0.9 \%$ から、投与後には $7.1 \pm 0.9 \%$ へと有意に $(p<0.01)$ 低下した。BMI は投与前 27.6 $\pm 4.8 \mathrm{~kg} / \mathrm{m} / \mathrm{m}$ に対し、投与後は $27.4 \pm$ $4.4 \mathrm{~kg} / \mathrm{m} / \mathrm{m}$ で投与前後で変化しなかった。 同様に、T. Chol 、TG、HDL - Chol はいず れも投与前後で有意な変動は示さなかった。 (2) SU 剂群での成績
男性 6 名、女性 4 名の合計 10 名で、年齢 は $53.2 \pm 11.1$ 才であった。FPG は投与前 $179.0 \pm 24.8 \mathrm{mg} / \mathrm{dl}$ に対し、投与後は $183.0 \pm 21.9 \mathrm{mg} / \mathrm{dl}$ で投与前後で有意な 変動は示さなかった。一方、HbA1C は投与 前の $8.6 \pm 0.9 \%$ から、投与後には $7.8 \pm$ $0.7 \%$ ヘと有意に $(p<0.01)$ 低下した。 $B M I$ は投与前 $23.3 \pm 2.6 \mathrm{~kg} / \mathrm{m} / \mathrm{m}$ に対し、 投与後は $23.4 \pm 2.7 \mathrm{~kg} / \mathrm{m} / \mathrm{m}$ で投与前後で 有意な変動は示さなかった。同様に、T.Chol 、 TG、HDL - Chol はいずれも投与前後で有意 な変動は示さなかった。

( 3 ) F - IRI に及ぼす影響

$\alpha-\mathrm{GI}$ 投与前後で F-IRI が減少した例は 8 例あり、投与前の $10.6 \pm 3.0 \mu \mathrm{U} / \mathrm{ml}$ から、 投与後には $8.6 \pm 2.9 \mu \mathrm{U} / \mathrm{ml}$ へと低下し た。一方、 $\alpha-G \mid$ 投与前後で F - IRI が不変な いし増加した例は 9 例あり、投与前の $5.3 \pm$ $1.0 \mu \mathrm{U} / \mathrm{ml}$ から、投与後には $6.3 \pm 1.8 \mu$ $\mathrm{U} / \mathrm{ml}$ へと増加した。F - IRI 減少群の BMI は $27.2 \pm 4.3 \mathrm{~kg} / \mathrm{m} / \mathrm{m}$ に対し、F - IRI 増加群 の BMIは $22.4 \pm 1.9 \mathrm{~kg} / \mathrm{m} / \mathrm{m}$ で、F - IRI 減 少群の BMI が有意に $(p<0.01)$ 高値であっ た。

(結論)

NIDDM 患者に $\alpha$-GI を投与した場合、食 事療法単独でも、SU 剂併用時でも血糖コント ロールの改善が期待される。さらに、肥満例 ではインスリン抵抗性の改善が、非肥満例で はインスリン分泌能の改善が予想される。 
水戸協同病院 代謝内分泌内科 遅野井 健 朴 明俊 斎藤三代子 内海信雄

$\alpha$-glucosidase阻害剤、仢不以、中性脂肪

【はじめに】 $\alpha$-glucosidase阻害剤は糖質の 分解を阻害することによってグルコースとしての 吸収を遅延させ、食後の過血糖を抑制する糖 尿病治療薬である。また、その特徵は血中仡 スリレベルを増加させずに薬効を示すことであ り、現在一般的な経口血糖降下剂であるSU棛 や 仅双注射などとは全く作用機序が異なり、 高脂血症を始めとした似杊 レベル上昇による 悪影響を回避できるものと思われる。そこで、 従来の薬物治療を $\alpha-$ glucosidase阻害剤へ変 更することの可否、およびその利点について 検討することを目的として本研究を行った。

【対象および方法】少量のSU䨩（1Tab/day以 下）または傝ツ（中間型12u/day以下）を使 用中で、比較的良好な血糖コントロール（HbA1c:5 〜 7\%) を維持している患者（SU剤25例、仅对 ン23例）を対象とした。（表 1 ）

\begin{tabular}{|c|c|c|c|}
\hline & 例数 $(M / F)$ & 年齢 (歳) & BMI \\
\hline 全例 & $48(20 / 28)$ & $59.3 \pm 1.4$ & $22.8 \pm 0.4$ \\
\hline 経口剂 & $25(9 / 16)$ & $59.4 \pm 1.7$ & $22.4 \pm 0.6$ \\
\hline インスリ & $23(11 / 12)$ & $59.2 \pm 2.3$ & $23.2 \pm 0.7$ \\
\hline
\end{tabular}

従来の治療法を $\alpha$-glucosidase 阻害剂（グ ルコバイ $300 \mathrm{mg} /$ day）に変更し、8週後と 12 週後 に HbA1cにて下記基準に従って薬効を判定し た。また、変更前と12週後には们双以、 $c-ヘ^{\circ} 7^{\circ}$ チド、コレステロール、HDL-コレステロロール、中性脂肪を早朝 空腹時採血にて測定した。《薬効判定基準》 - 改善 : HbAlc 0.7\%以上の改善 - やや改善 : $\mathrm{HbA1c} 0.4 \sim 0.6 \%$ の改善 - 不変 : HbA1c \pm 0.3 $\%$ の変動・悪化 : HbA1c $0.3 \%$ 以上の悪化。
【結果および考察】まず薬効について検討す ると、表 2 に示すごとく 8 週後においては約 65\%が不変以上と良好であり、12週後におい

表 2 治療法変更後の血糖了吅-凡状態

\begin{tabular}{c|l|rcrl}
\hline \multicolumn{2}{c|}{} & 改善 & やや改善 & 不変 & 悪化 \\
\hline 8 & 全例 & 9.1 & 6.8 & 47.7 & 36.4 \\
\cline { 2 - 6 } 週 & 経ロ剂 & 8.7 & 4.3 & 34.8 & 52.2 \\
後 & インスリ & 9.5 & 9.5 & 61.9 & 19.0 \\
\hline 12 & 全例 & 2.1 & 6.3 & 50.0 & 41.6 \\
\cline { 2 - 6 } 週 & 経ロ剂 & 4.0 & 4.0 & 44.0 & 48.0 \\
後 & インスリ & 0 & 8.7 & 56.5 & 34.8 \\
\hline
\end{tabular}

ても約 $60 \%$ が良好であった。なお、付对から の変更例では8週後の悪化例は $19 \%$ みであっ

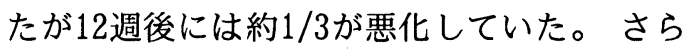
に、経口剤からの変更例では $8 、 12$ 週後とも 約半数が悪化しており、悪化率は付对から の変更例より高率であった。この一因は服薬 コンプライアンス の低下に基づくものと思われ、管 理上注意を要するものと思われた。つぎに、 血清脂質および仅林レ゙ルの変動を検討する と、表 3 に示すごとく中性脂肪とIRIが治療 表 3 脂質およびインスリルベルの変動

\begin{tabular}{|c|c|c|}
\hline & 前 & 12週後 \\
\hline コレステロール & $192.2 \pm 5.2$ & $192.8 \pm 5.7$ \\
\hline HDLーコレステロール & $49.6 \pm 1.9$ & $49.5 \pm 2.0$ \\
\hline 中性脂肪 ${ }^{a}$ & $95.8 \pm 8.8$ & $84.5 \pm 6.2^{*}$ \\
\hline $\mathrm{IRI}(\mu \mathrm{U} / \mathrm{ml})$ & $9.0 \pm 0.6$ & $7.7 \pm 0.5^{*}$ \\
\hline $\mathrm{CPR}(\mathrm{ng} / \mathrm{ml})$ & $1.6 \pm 0.1$ & $1.7 \pm 0.1$ \\
\hline
\end{tabular}

法変更前に比して12週後で低下していた。

【結語】 $\alpha$-glucosidase阻害剂は、60\%以上

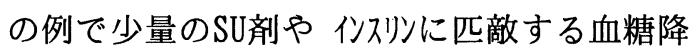
下作用を有し、それらに比して中性脂肪や们

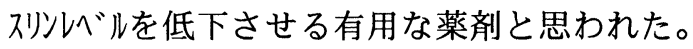




\section{$2 \mathrm{E} 17$ 榶尿病, 合併症予防の経浐的奻果}

安城更生病院内科 山本昌弘, 川久保明利, 垣屋 聡, 月山克史

糖尿病, 経済効果, 合併症予防

[はじめに]糖尿病患者は一生, 医療機関 との関係を打ち切ることはできない，その生 涯に必要とする経費は莫大なものとなると思 われるので, その推計を試みた。

[方法］NIDDM患者の一生を次の様に仮定し， 1995年 4月現在の診療報酬点数表を基に保健 点数を算定した．食事は点数に換算した。 40 才; 糖尿病指摘, 食事療法, 運動療法にて 良好な血糖値· HbA1c値を保つ.

45才; 榶尿病発症, 3 週間の治療, 教育入院 を受け，経口血糖降下剂開始. 以降月 1 回, 糖尿病外来通院, 検査と投薬を受ける.

55才；的確な食事，運動療法を行い，経口血 糖降下剂を内服していたが、コントロール不 十分となり，中間型インスリン 2 回／日の自 己注射を始める。血糖自己測定を月20回程度 行う. 高血圧, 高脂血症, 神経障害を合併. 65才; 網膜症の為両眼に光凝固術を受ける. 75才；心笳梗塞にて外来死.

[結果] 1) 治療・教育入院期間; 入院医学 管理料, 薬剤管理指導料, 特 3 看護, 食事, 胸部X-P, 腹部エコー, 神経伝達速度, 負荷心 電図, 精密眼底, 投薬 (グリミクロン $80 \mathrm{mg}$ ) 等, 入院院期間の総負担点数（給食費を含む） は39, 471点と算出.

2)通院期間- 1,45 才 24 才; 再診料, 定期検 查, 投薬等 $1,755 /$ 月, $21,060 /$ 年, 胸部 $\mathrm{x}-$ $\mathrm{p}$, 眼底検查, 腹部エコ一, 負荷心電困等年間 定期検查を含め $22,260 /$ 年, 計 $222,600 / 10$ 年 と算出.
3)通院期間-2，55才〜75才;

ペンフィル 30R自己注射, 自己血糖測定を行 い合併症のための投薬を受け, 検查は通院期 間-1と同様に行うものと仮定して，6，469／月， $6,469 \times 12=77,628 /$ 年, $1,572,560 / 20$ 年と算 出した. 光固左各 1 回 $16,200 \times 2=32,400$ を 加えると， $1,653,560 / 20$ 年となる. 生涯必要 医療点数は $1,867,031$ 点 $/ 30$ 年と計算される. もし，合併症無しに生涯を終えることができ れば必要点数は667，800点となる。

同様にIDDM患者の一生を，20才で発症，イ ンスリン治療開始, 40才で高血圧, 神経障害 を合併，50才で腎症の為シャント作製，人工 透析開始，70才で一生を終えたと仮定した時 その生涯必要点数は， 8,858，588点と算出され た。もし，合併症無しに，生涯を終えること ができれば必要点数は2,653，200点となる.

[まとめ] 糖尿病患者がその一生を終之 るには莫大な医療費を必要とすることが示さ れた。もし，合併症無しに一生を過ごすこと ができれば，NIDDMでは約1000万円の，IDDMで は粎6000万円の医療費が不要となることが推 定された。厳格なコントロールを行えば予防 可能な合併症が存在することは，糖尿病に見 られる特性であり, 糖尿病そのものと合併症 の防止は，患者の快適な人生を保障すること ばかりでなく，医療経済面からみても重大な 課題と言えよう。 
$2 \mathrm{E} 18$ 当院の糖尿病患者教育の実際

患者の立場に立った食事指導をめざして

○浜岡昌美 荆口由紀美 野沢由香 稲葉美香 （㴟生連滑川病院東病棟三階）

糖尿病 受け持与制 食品交換

当院内科病棟において、従来月二回の院内 全体での糖尿病教室と手作りのフードモデル や大判カルタの利用 またビデオによる学習 や糖尿病しおりの読みあわせなど計画立てて 週一回の集団指導を行ってきた。

しかし 最近では入院される糖尿病患者の年 齡層が、高年齢から中高年齢の㗢き盛りにと 变化してきており、現状の指導方法ではライ フスタイルにあわせた援助が困難であると考 えた。

糖尿病患者の教育は患者自身に「糖尿病とは 何か」という知識を教え、自己管理のための テクニックを指導することが教育の主体であ る。単に知識をあたえ技術指導をするだけで なく、患者に動機づけをして行動そのものを 変容させるところまでいかないと到達したと 言えない。療養過程での不満や不安などの良 き理解者となって、本人にも自分の考えや思 いを検討してもらうことが大切である。

また、食品交換表を抵抗なく使用し自己管理 する習慣を早期に身につけることで、退院後 の生活に自信がもてるように指導しなければ ならない。

そこで、私達糖尿病委員四名が糖尿病患者を 積極的に受け持ち、入院早期から生活指導に かかわった。従来の方法である糖尿病セット 及び万歩計の準備 指示カロリ一や運動量の 表示に加光、受け持ち看護婦が入院時チェッ
クリストを患者に渡すと同時に糖尿病指導チ エカリストから情報を得、個別的に問題点を 見いだし指導の方向性を明確にした。 このようなかかわり方で患者を一人の人とし て理解し、不安の表出しやすい状況を作って いった。

特に食事指導においては 基礎食を早期に理 解するため、毎日看護婦とともに食品分類表 を参考に病院食を分類し、ノートに記載して もらった。繰り返し繰り返し食品分類につい て復習したことで、食品交換表が抵抗なく使 用可能となった。退院後は患者の負担になら ない程度で献立をノートに記載してもらい、 再診日に個人の指示カロリーが守られている か確認し励ました。

さらに退院後の生活において 血糖コントロ 一ルが確認され、自己管理がより確実に実施 できるように S M B Gの指導も積極的に進め た。

これらの結果 退院後の日常生活に良い影響 が得られたので報告する。 


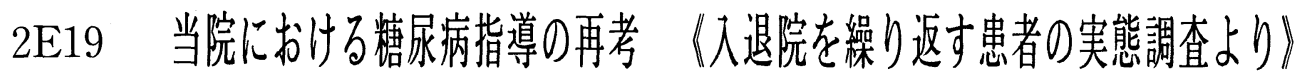

\section{○那須 由美子 - 宮前 明実 - 榎崎 紀恵 - 他,内科病棟 看謢婦一同}

〔内科〕品川晃二

【広島県厚生連府中会病院】

【はじめに】 糖尿病は文明の進歩と共に増 加してきており当院においても教育入院を実 施し自己管理の向上に努めているが、入退院 を繰り返しその都度症状が悪化し、合併症を 伴うといった症例も少なくない。当病棟入院 患者のうち糖尿病患者の占める割合は $20 \%$ に のぼり、内約半数が再入院である。今回その 点を重視し、入退院を繰り返す患者の理由や 背景を知ると共に、現在行っている糖尿病指 導を見直したことについて報告する。

【調查対象と方法】過去 5 年間の実態調查 患者 200 名を無作為に選び各項目別に調查し た。性別は男性 126 人、女性74人。年歯は図 1 、罹病期間は図 2 、入院回数は図 3 、参照 。図 4 は罹病期間が長ければ合併症が多いと 思われ、又短いにもかかわらず合併症を持ち 合わせている患者が多いという現状も表れた 【調査後の問題点】(1)自己流で誤った認識 。(2)自己管理が制限される。(3)合併症の危機 感が乏しい。(4)地域的に高歯者が多い。

【当院の指導の現状】(1)テキスト・パンフ レットによる個人指導。(2)ビデオでの指導。

(3)食事指導。(4)糖尿病教室。(5)チェックリス トによる評価。

【考察】調查の結果自己管理が出来ない原 因は、インシュリン注射、経口剂をつかって いるから大丈夫、と安易な気持ちとなり、食 生活が乱れるなど自己に対する甘えと考える 。病気は知識として理解は出来ているが、実 生活の中で自己管理の実践が困難になる事も
多い。

過疎化傾向にあるこの地域では、一人暮ら しや老夫婦だけで生活している患者も多く、 周りの援助が期待できない。又高齢からくる 理解力の低下や、本人の諦めもあり「先は短 いから好きな物を食べたい。」と思っている 老人も多く、指導が難しい。そして食事を作 る人が本人でない場合や、家族の知識不足で 協力が得られないケースもあり、訪問指導の 大切さを痛感した。

【おわりに】これまでの看護は、一方的で 個別性に欠けていた。今後は、個人的な関わ りあいを密にし、健康管理課との連携をとり 充実した指導を展開したい。

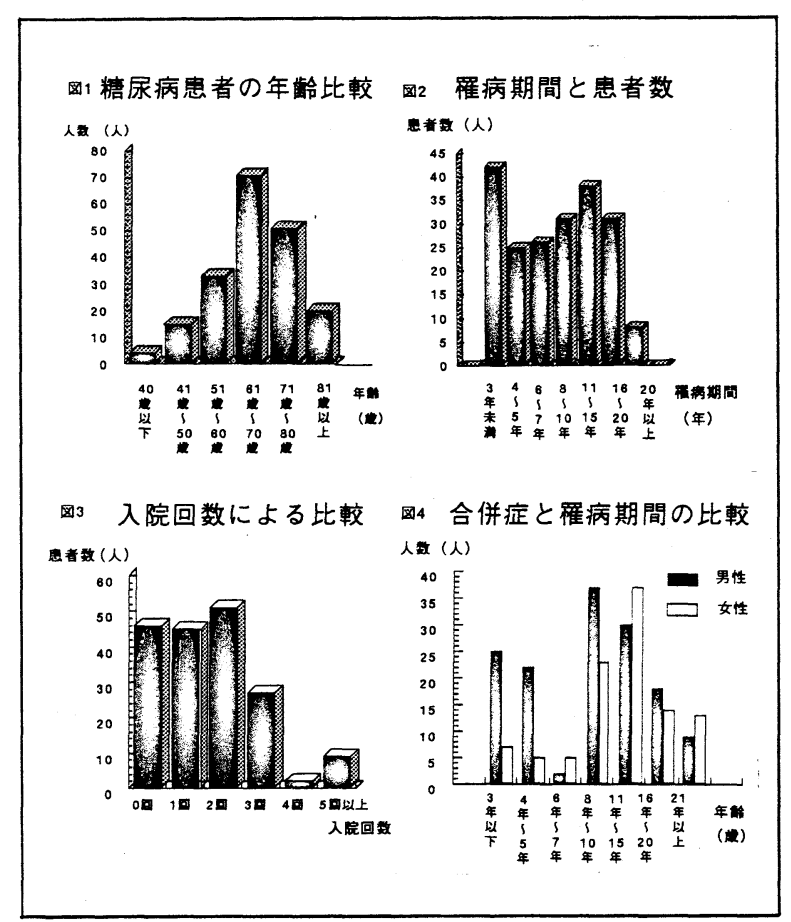


2E20 糖尿病患者教育における認識度調查 (へモグロビンA 1 c 值の認識について)

$\begin{array}{cccc}\text { O山口 桂 } & \text { 湯上小百合 } & \text { 石原勝 } & \text { 佐藤良美 } \\ \text { 坪内治巳 } & \text { 三輪幸利 } & \text { 水林竜一 揁 } \\ \text { 長嶋 誠 } & \text { (愛知県厚生連 海南病院) }\end{array}$

・ヘモグロビンA 1 c ・糖尿病患者教育

はじめに

患者の病気に対する認識度を知るため個別ア ンケート調査を実施したので報告する。

方法

平成 6 年 9 月〜 10月にかけて，当院糖尿病外 来患者で個別アンケート調査にて回答を得た 355 名（男185名・女170名）を対象とした。 結果

1 ) 回答者の年代別構成（表 1 )

\begin{tabular}{|c|c|c|c|c|c|c|}
\hline 年代 & 30 代 $\downarrow$ & 30 代 & 40 代 & 50 代 & 60 代 & 70 代 \\
\hline 例数 & 5人 & $11 人$ & 47人 & 99人 & $136 人$ & $57 \lambda$ \\
\hline 割合 & $1.4 \%$ & $3.1 \%$ & 13. $2 \%$ & $27.9 \%$ & $38.3 \%$ & $16.1 \%$ \\
\hline
\end{tabular}

2 ) 表 2 には治療法と $\mathrm{HbA} 1 \mathrm{c}$ の認識度と糖尿 病教室参加の有無により分類した患者の割合 とHbA1c值を一覧表にした。

各治療法では价则治療者83名(23.4\%), 経口 剂内服者170名 (47.9\%), 食事療法者102名

(28.7\%)であった。

各群で自分のHbA1c值を認識している人は仿 リン群では37. 3\%で経口剂内服群・食事療法群 ではそれぞれ18.8\%・19.6\%であった。 どの治療法群においてもHbA1c認識群で有意
に低值を示した。また，外来糖尿病教室に関 しては経口剂内服群で38. 2\%, 食事療法群21. 6\%，インスリ群13.0\%が過去 5 年以内に教室を受 講していた。受講者と非受講者の比較では各 療法群においてとも $\mathrm{HbA} 1 \mathrm{c}$ 值に差は認めなか った。インスリン治療群は外来糖尿病教室受講率 が最低であるにも関わらず，HbA1c值の理解 率が高かった。この事は教育入院時や測定指 導の際に充分な教育指導がなされたためと考 えられた。まとめ

1 ) 外来糖尿病患者において自分の $\mathrm{HbA1 \textrm {c }}$ 認識している群は認識していない群に比べ, 有意にHbA1c值が低值でコントールが良好であっ た。

2 ) 价リン治療群は外来糖尿病教室受講率が 低いもののHbA1c值の理解度は他療法群に比 べ良好であり，教育入院・自己血糖指導の際 の教育の成果と考えられる。

3) 経口剂内服者・食事療法者において HbA1 $\mathrm{c}$ 值の認識度は 2 割程度であり, より多く参 加者を得るため外来糖尿病教室の開催日や講 義内容を検討する必要があると思われた。

表 2)

\begin{tabular}{|c|c|c|c|c|c|c|c|c|c|}
\hline \multirow[b]{3}{*}{ 対象者（355名） } & \multicolumn{3}{|c|}{ イシシュリソ治療法群 } & \multicolumn{3}{|c|}{ 経口骫内服群 } & \multicolumn{3}{|l|}{ 食事療法群 } \\
\hline & \multicolumn{3}{|c|}{ 人数 (\%) $\mathrm{HbAIC}(\%) \mathrm{M} \pm \mathrm{SD}$} & \multicolumn{3}{|c|}{ 人数 (\%) $\mathrm{HbA1 \textrm {c }}(\%) \mathrm{M} \pm \mathrm{SD}$} & \multicolumn{3}{|c|}{\begin{tabular}{|l|l|} 
人数 (\%) & HbAlC $(\%) \mathrm{M} \pm \mathrm{SD}$ \\
\end{tabular}} \\
\hline & $83(23.4 \%)$ & $8.8 \pm 1.6$ & & $170(47.9 \%)$ & $8.3 \pm 1.8$ & & $102(28.7 \%)$ & $7.3 \pm 1.7$ & \\
\hline HbAlC認識している & $31(37.3 \%)$ & $7.3 \pm 1.2$ & & $32(18.8 \%)$ & $7.3 \pm 1.1$ & & $20(19.6 \%)$ & $6.7 \pm 1.0$ & \\
\hline HbAIC認識してない & $52(62.7 \%)$ & $9.1 \pm 1.6$ & $P<0.01$ & $138(81.2 \%)$ & $8.5 \pm 1.8$ & $P<0.01$ & $82(80.4 \%)$ & $7.4 \pm 1.7$ & $P<0.01$ \\
\hline 教窒受講した & $11(13.0 \%)$ & $9.1 \pm 1.4$ & & $65(38.2 \%)$ & $8.1 \pm 1.5$ & & $22(21.6 \%)$ & $7.3 \pm 1.4$ & \\
\hline 受講してない & $72(87.0 \%)$ & $8.6 \pm 1.6$ & N.S & $105(61.8 \%)$ & $8.4 \pm 1.9$ & N.S & $80(78.4 \%)$ & $7.3 \pm 1.8$ & N.S \\
\hline
\end{tabular}




\title{
$2 \mathrm{E} 21$ 若年者を対象とした糖尿病療養に関するアンケート調査
}

\author{
水戸協同病院 看護科 道口佐多子 加藤 智子 柴田 芳枝 石川 京子 \\ 浅川 洋子 粕谷 栄子 萩野谷光江
}

代謝内分泌内科 遅野井 健 斎藤三代子 朴 明俊 内海 信雄

若年発症糖尿病患者、アンケート調查、社会的理解

【はじめに】糖尿病は年々増加傾向にあり、 若年発症糖尿病患者も決して特殊なものでは なくなってきている。現在当院においては、 糖尿病外来通院中の患者 2000 人のうち約 $10 \%$ が45歳未満の比較的若い人で占められており、 その数は年々増加傾向にある。この年代の患 者は、成長および人生形成の面で社会との関 わりも多く、中高年の患者とは異なる問題点 を抱えていることが少なくない。そこで今回 比較的若い糖尿病患者を対象として、療養に かかわる問題点を明らかにすることを目的と してアンケート調査を実施した。

【対象】対象は45歳未満の糖尿病患者 96 名 （男性45名、女性51名、平均年齢 33.2歳、平 均HbA1C 7.8\%) でIDDM35名、NIDDM60名、膵性 1名、既婚者 64 名、未婚者32名であった。

【結果】（表 1 に示した）
【考察】今回のアンケート調査の結果、療養 の上の負担は食事療法が最も大変であり、守 られにくかった。これは、糖尿病患者一般に いえることである。しかし、進学、就職、結 婚、出産など、合併症以外にもこの年代特有 の精神的な不安要因が加わり、さらに療養を 困難なものにしているものと思われた。さら に、病気に対する社会的偏見を感じている例 が約半数認められ、病気のことを他人に知ら

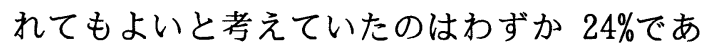
った。その結果 30〜 40\%の患者が先生や会社 の上司に病気のことを知らせておらず、臨床 的にもコントロールを乱す要因として無視で きるものではないと思われた。以上のことは、 若い患者が糖尿病の療養を続けながら社会生 活をすることの困難さを示すものと思われ、 糖尿病という疾患の認知と同時に患者に対す る社会的理解の必要性を痛感した。

表 1 アンケート結果

I ）日常生活での負担

(1) 食事療法

(2) 注射や飲み薬

(3) 運動療法

(4) 定期的な通院

(5) 規則的な生活
$82.4 \%$ 外 食 $46.2 \%$

菓子類 $39.6 \%$

PルIール $24.2 \%$
II）療養の上で、守られていない事

(1) 食事療法

$80.2 \%$ 外 食 $23.1 \%$

菓子類 $39.6 \%$

P川I-ll $14.3 \%$
(2) 運動療法 $57.1 \%$

(3) 規則的な生活 $30.8 \%$

(4) 注射や飲み薬 $17.1 \%$

(5) 定期的な通院 $7.2 \%$

III）病気のことを、話してある人
(1) 特定の友人
$83.5 \%$
(2) 会社の上司
$67.2 \%$
(3) 学校の先生
$63.2 \%$

VI）今後の人生への不安

(1) 合併症出現

$91.2 \%$

(2) 結 婚

$62.1 \%$

(3) 出 産

$55.5 \%$

(4) 就職や出世

$21.5 \%$

IV) 病気のために、困った事
(1) 就職や出世 $21.6 \%$
(2) 入学予進学 $10.5 \%$
(3) 結婚や出産
$6.6 \%$

$\mathrm{V})$ 病気を他人に知られる事について

VII）今後社会に望む事

(1) 糖尿病に対する偏見をなくして欲しい 50.5\%

(2) 糖尿病を隠さなくてすむ社会が欲しい $30.8 \%$

(3) 同じ悩みを持つ人の意見交換の場が欲しい $20.9 \%$ 
○二階堂 正美、宮津 晶、西塚 裕子、山田 文子 (取手協同病院看護科)

医療従事者の連携

【はじめに】近年文明病とも言われている糖 尿病患者が年々増加の一途をたどっている。 当院においては平成 6 年10月より糖尿病患者 の教育を重要視し、積極的に取り組んでいる。 当科では 4 週間を教育期間とし、医師・看 護婦・栄養士・理学療法士が協力しあいなが ら患者及び家族指導を行った結果、自己管理 の意欲向上につながったので現状報告する。

【教育期間及び方法】

1. 糖尿病教室 $=$ 毎週金曜日に医師による集 団及び個別指導。

日 2 . 運動療法=第 $1 、 3$ 水曜日に理学療法士 による運動療法の説明及び実施。

3 . 栄養指導 $=$ 第 $2 、 4$ 水曜日に栄養士によ る集団指導、及び退院前の個別指導。

4. ビデオ教室 $=$ 毎週火・木曜日に12種類の ビデオを 4 週間に分けて上映。

5 . 看護婦による個別指導 $=4$ 部構成のパン フレット（糖尿病とは・糖尿病の食事療法・ 薬物 \&運動療法・合併症＆救急処置）を使用 した個別指導。

6. 糖友会主催による糖尿病教室への参加。

【看護婦による個別指導の現状】

1. 入院時、15項目からなる指導リス卜を使 い、指導方針、到達目標を決める。

2. 1 週間に 1 度、チェックリストを用い評 価をし理解度の低い点を個別に指導する。

3.インスリン注射を必要とする患者には、 16項目からなるチェックリストを用いて毎回 手技、実践の指導を行う。
患者の意欲向上

4. 食事指導として、食事量の測定、分類 · 単位数の記録を推進する。不可能な患者に対 しては到達目標を決め指導をする。

5. 1 週間に 1 度カンファレンスを行い、他 のスタッフと連携をとり指導が中断されない ようにする。

【結果】チェックリスト使用により患者を十 分把握した上での指導ができ、患者の知識向 上もチェックリスト上で明らかとなった。ま た、パンフレットや指導に対し興味を示し、 血糖値を記入したり質問等が増える患者が多 くなった。反面、指導に対し無関心、拒否的 な患者や家族もあり、入院期間や血糖コント ロールに影響を与えた。

【考察】患者は知識を得たことが自信となり 意欲向上につながったが患者の病識や行動に よって血糖值が大きく変化することなどを認 識でき、指導の重要性を強く感じた。しかし 当科においては高齢者や他疾患を合併してい る患者が多く、知識向上に消極的なケースも あり、今後患者及び家族への数多い声かけや 他の患者との係り、糖友会参加などを通じて アプローチしていきたいと考えている。

【おわりに】当科においては血糖コントロー ル不良の患者が主である。今後私達は患者の 自己管理推進に向け、職場でのカンファレン 又強化や他院への研修、糖友会活動などに積 極的に参加し、より良い看護を目指していき たい。 


\section{$2 \mathrm{E} 23$ 糖尿病患者の治療中断を防止するために 一患者登録の試み一 \\ ○川上恵美子小川豊子永井美佐子 三浦美子 \\ 原里美大桃啓子八幡和明 \\ (長岡中央綜合病院内科外来)}

糖尿病 治療中断 患者登録

はじめに

糖尿病は、長期にわたる治療継続が必要で ある。しかし、平成 6 年の調查で当院内科外 来通院患者の $38 \%$ が、糖尿病の治療を中断し ていた。その患者に、再受診を勧奨したが、 応じた者は少なかった。治療を継続させるに は、患者の病識を高めていくことが必要であ る。そこで、登録システムを導入した。その 紹介と今後の課題を検討した。

I システムの紹介

(1)対象者

・アルコール、間食が問題

・検診で指摘されて放置したことがある人

・治療中断の既往のある人

・食事療法のみで病気を軽く考えている人

・仕事が不規則な人

・退院後特に経過を見ていく必要のある人

- 独身男性 他

(2)体制

1) 面接の方法

- 専任看護婦 4 名

・診察の待ち時間に行なう

・場所は内科外来 時間は10 20分

・診療日ごと（2４ 週）ただし病識の向 上と共に間隔を開けていく

2 ) 医師と看護婦とで各人の問題点の検討 (月 1 回)

3） 3 ケ月以上をめどに治療中断している 患者への対応を検討 (3)記録（a〜dをファイルに保管） a 問診票（患者が初回の面接時に記入）

$\mathrm{b}$ 個人情報

C 検査チェック票

d 経過記録

II システムの現状（平成 7 年 4 月末現在）

(1)人数男性 37 人 女性 8 人 計 45 人

(2)年齢 $\quad 30$ 77才 平均 50.9 才

(3)配偶者有34人 無11人

(4)職業有職 34 人 無職 3 人

(5)薬物治療者 21 人

(6)面接延へ回数 105 回

(7)登録理由の

分類 (重複あり) \begin{tabular}{|ll|cc} 
間食 & 食 & 13 人 \\
中 & 断 & 7 人 \\
独 & 身 & 7 人 & 他 \\
\hline
\end{tabular}

III 今後の課題

現在登録している45人、ほとんどが、この システムを肯定的に受入れている。しかし、 すでに 5 名が 2 力月以上受診していない。そ の 5 名全てが、登録後 1 ～ 2 回の面接回数で ある。その原因として、初回面接時の教育が、 不充分である事が考えられる。今後さらに初 回の面接に力を入れる必要があると思われる。

今後増えていく患者に、より効果的に指導 するために、面接の方法や、時間設定、指導 のための場所を検討し、指導者のレベルアッ プをはかる必要がある。

てのシステムの導入により患者の治療への意 識を高めると共に、私たち看護者の外来看護 に対する意識を高めることにもつながった。 


\section{E24 糖尿病に発症した Reflex Sympathetic Dystrophy の 1 症例}

$\begin{array}{llll}\text { 水林 } & \text { 竜一 } & \text { 羽賀 } & \text { 達也 長嶋 誠 } \\ \text { 大谷 } & \text { 由幸 } & \text { 菅田 } & \text { 忠夫 } \\ \text { 愛知厚生連 } & \text { 海南病院 内科 }\end{array}$

key word: reflex sympathetic dystrophy

\section{【症例】47歳男性、主訴 体重減少 左手のし} びれ、入院の 1 年 3 月前に糖尿病を指摘され ていたが放置。13kgの体重減少有り。受診の1 週間前に樽酒を割ってから左手掌にしびれを 感じるようになる。

【人院時現症】身長 $170.5 \mathrm{~cm}$ 体重 $53 \mathrm{~kg}$ 脈拍 8 $4 /$ min 血圧 $132 / 76 m m H g$ 聴打診異常なし 腱反射正常、異常反射認めず抹消拍動 動脈 拍動はすべて触知する 知覚 両足MP関節よ り遠位に知覚低下、左手掌および手背とう側 に知覚低下。

【初診時検査】WBC $5,800 / \mu 1$ RBC $435 \times 10^{4} /$ $\mu 1 \mathrm{Hb} 14.7 \mathrm{~g} / \mathrm{d} 1$ P1t $40.6 \times 10^{4} / \mu 1$ TP 6 . $7 \mathrm{~g} / \mathrm{dl}$ Alb $3.9 \mathrm{~g} / \mathrm{d} 1$ G0T $41 \mathrm{IU} / 1$ GPT $35 \mathrm{IU}$ $/ 1$ ALP 190IU/1 RA 16IU/m1以下 $\gamma$-GTP $455 \mathrm{IU} / 1 \quad \mathrm{~T}-\mathrm{Bi} 1 \quad 0.5 \mathrm{mg} / \mathrm{dl} \quad$ ESR $18 \mathrm{~mm} / \mathrm{hr} \quad \mathrm{BU}$ N $8.4 \mathrm{mg} / \mathrm{d} 1 \quad$ Cr $0.7 \mathrm{mg} / \mathrm{d} 1 \quad \mathrm{Na} 139 \mathrm{mEq} / 1 \quad \mathrm{~K}$ 4. $0 \mathrm{mEq} / 1 \quad$ C1 $102 \mathrm{mEq} / 1 \quad$ Ca $4.6 \mathrm{mEq} / 1 \quad \mathrm{~T}-\mathrm{Ch}$ o $177 \mathrm{mg} / \mathrm{dl}$ TG $84 \mathrm{mg} / \mathrm{d} 1$ HDL-C $72 \mathrm{mg} / \mathrm{dl} \quad \mathrm{C}$ $\mathrm{RP} 0.0 \mathrm{mg} / \mathrm{dl} \quad \mathrm{LDH} 104 \mathrm{IU} / 1 \quad \mathrm{HbA}_{\mathrm{l}} \mathrm{c} 13.1 \%$ $\mathrm{U}$-Alb $11.6 \mu \mathrm{mg} / \mathrm{g} \cdot \mathrm{Cr} \quad 24 \mathrm{~h}-\mathrm{Clcre} 86.7 \mathrm{ml} / \mathrm{mi}$ n

【経過】23単位食、インスリンN P H 朝18単位、 夕8単位にて血糖は良好にコントロールされ る。左手のしびれと左手関節周囲の疼痛は残 るものの1力月後退院。退院後左上肢の痛みに 加え運動制限が出現し4カ月ご再入院となる。 【入院時現症】体重 $56 \mathrm{~kg}$ 左上肢の関節の可動 域の制限あり 左上肢の筋萎縮(M. del toideu s, M. biceps brachi i, M. brachioradial is,
M. flexor carpi radialis) 左手指の腫脹、 拘縮、皮膚萎縮、指紋の消失。左手関節尺側背 側の腫脹之圧痛。上肢の知覚異常はない。

【入院後検査】上肢単純XP 左の骨萎縮著明。 頭部CT、頝部MRI 異常無し。骨シンチグラフィ 一 左肩及び左手関節にTcの集積有り。

【経過】臨床症状より反射性交感神経性萎縮症、 reflex sympathetic dystrophy と診断。epal restat, etizolam, sulpiride, beraprostを投 与する。入院1力月半で関節の腫脹は改善する。 左手の腫脹の減少と共に上肢の運動制限も改 善してくる。入院2力月ですべての関節につい て改善が認められ退院となる。退院後も入院 時と同じ投薬を受け退院4力月後には諸症状 の改善を認める。

【考察】RSDは軽微な外傷などの誘因で起きる 交感神経の局所での不安定性を伴う有痛性疾 患である。本症例の特徴として1. 血糖コント ロール改善時に症状が悪化したこと。2. 精神 安定剤と共にARI. PGE1製剤の併用で改善した ことである。急激な血糖のコントロールは、抹 消神経障害や自律神経の一時的な増悪を引き 起こすことがあり、本症例もこれに当てはま ると思われる。PGE1製剤など血管拡張剤は、従 来RSDの治療に有効と言われているが、糖尿病 に合併したRSDではARIも有効である可能性も 示唆された。 
○椎貝 達夫、加藤 邦彦、前田 益孝、大和田 章

(取手協同病院内科)

\section{糖尿病腎症ミクロアルブミン 低蛋白食}

【目的】低蛋白食 (LPD) が糖尿病の尿 アル゙シン 排泄量 (UAE) を減少させるか否か検討した。

【方法】ミ叭ル犬゙ン尿を呈するNIDDM 12例につ き、PIを段階的に減少させる指導を行い、1 か月毎にPIと UAEとの関係をみた。PIは 24 時 間蓄尿Maroniらの式で求めた。UAEは同じく 24時間蓄尿から RIAで求めた。UAEはに影響 する可能性のある変換酵素阻害薬、 吅久代 等の投与は避けた。

【結果】12例の背景因子は表 1 に示した。PI とUAEの関係をみると、困 1 に示すように両 者の相関が $\mathrm{r}=0.78$ と高い例と、図 2 に示すよ うに $r=0.35$ と相関性が低い例とがあった。全 例の相関係数の分布を示したのが図 3

で、 $\mathrm{r} \geqq 0.6$ を示した例は12例中 4 例 (33.3\%) であった。また $\mathrm{HbA}_{1} \mathrm{c}$ とこの相関係数との間 には一定の関係はなかった。

【考察】今回の結果では LPDに応じてUAE が 減少する例は $33 \%$ 程度と推測され、すべての 例に有効とは考えられなかった。われわれは すでに高度蛋白尿を呈し腎不全を伴うDNのPI と尿蛋白排泄量との相関を求め、 $\mathrm{r} \geqq 0.6$ の例 は15例中9 例、60\%であった（図3に○で示し た。第38回日本腎臓学会報告予定）。DNから

表 1 背景因子

\begin{tabular}{cc}
\hline 男 $/$ 女 & $6 / 6$ \\
年齢 & $55 \pm 2.3$ \\
罹病歴 & $7.9 \pm 1.1$ \\
Ccr & $80.8 \pm 6.3$ \\
HbAic & $8.5 \pm 0.5$ \\
\hline & $(m \pm S E)$
\end{tabular}

腎不全に至る深刻な事態を避けるためにはDN のもっとも早期像であるミ叭ル゙ミ尿期に LPD を行う必要があるだろう。なお LPDに対する 反応性の差異に、血糖調節の良・不良の関連 は否定的であった。

【結論】LPDはミ吅ル゙シン尿期の $36 \%$ 前後に有 効であり、DN 腎不全を予防するためにはこ の時期にまず LPDの適用を考えるべきであろ

う。

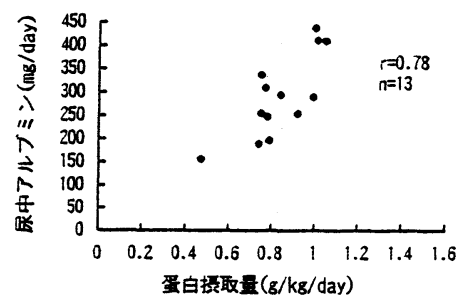

図 1 蛋白摂取量尿アルブミン排泄が 高い相関を示た例

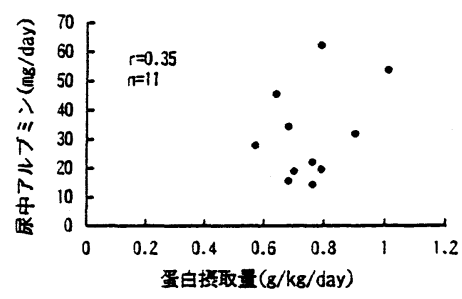

図 2 相関がみられない例

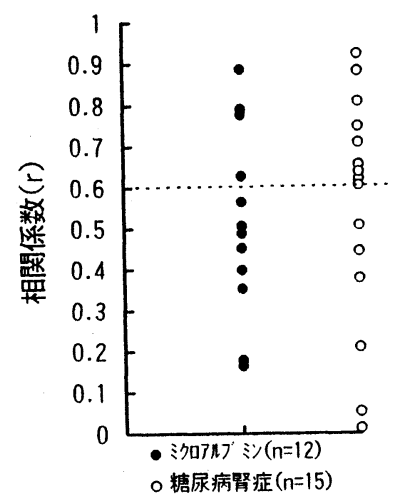

図 3 蛋白摂取量と尿アルブミン排泄量 または尿蛋白排泄量の相関係数の 分布 
2E26糖尿病性神経障害と肥満度との関連について

水戸協同病院 代謝内分泌内科 斎藤三代子 遅野井 健

朴明俊 内海 信雄

糖尿病性神経障害、肥満度、神経機能検査

【はじめに】糖尿病患者における肥満は合併 症悪化の一因子とされているが、神経障害と の関連についての報告は少ない。今回、体型 と神経障害との関連について、肥満度 (BMI) を指標として検討したので報告する。

【対象および方法】対象は糖尿病外来通院中 のNIDDM患者1000例（男性467例、女性533例、 平均年齢59.1歳）とし、対面法にて四肢の自 覚症状と自律神経症状を問診した。そのうち 354 例に安静時心電図RR間隔の変動係数 $\left(\mathrm{CV}_{\mathrm{RR}}\right)$ 、 振動覚閾値(VIB)、正中神経の運動および知 覚神経伝導速度 (MCV、SCV)を測定した。体容 積比(BMI)ごとに自覚症状と検查異常者の頻度 を検討した。なお、CVRR $<2 \% 、 V I B \geqq 25 \mu \mathrm{M}$ 、 $\mathrm{MCV}<50 \mathrm{~m} / \mathrm{s} 、 \mathrm{SCV}<55 \mathrm{~m} / \mathrm{s}$ を異常と判定した。

【結果】(1)BMIを20未満、20〜24、24以上の3 群に分けて検討した。四肢の自覚症状はBMI2 0未満の群で $53.5 \%$ と20～24の群の $38.1 \%$ に比し て高頻度であった。似治治療者の頻度もBMI 20 未満の群で $42.4 \%$ と高頻度であった。HbA1c $7 \%$ 以上者は3群間で差がなかったが、罹病期 間10年以上の者の頻度に差が認められた(表1)。

表 1 BMI別にみた神経症状の頻度と背景（全例）

\begin{tabular}{|c|c|c|c|}
\hline $\begin{array}{c}\text { BMI } \\
\text { 例 数 }\end{array}$ & $\begin{array}{c}20 \text { 未満 } \\
144\end{array}$ & $\begin{array}{c}20 \sim 24 \\
517\end{array}$ & $\begin{array}{c}24 \text { 以上 } \\
339 \\
\end{array}$ \\
\hline 四肢の自覚症状 & $53.5^{*}$ & 38.1 & 43.7 \\
\hline 自律神経症状 & 68.8 & 67.9 & 65.5 \\
\hline 仅杊治療者 & $42.4^{*}$ & 32.3 & 32.4 \\
\hline $\mathrm{HbA} 1 \mathrm{c} \geqq 7 \%$ & 19.4 & 17.4 & 20.1 \\
\hline 罹病期間 10 年以上 & 34.0 & 27.3 & $20.6^{*}$ \\
\hline
\end{tabular}

(2)そこで罹病期間を10年未満に限定すると、 四肢の自覚症状は、BMI 20 未満の群で $46.3 \%$ 、
24以上の群で $39.8 \%$ と20～24の群の32.2\%に比 していずれも高頻度であった。似则治療者は BMI20未満の群で $33.7 \%$ と多かったが、HbA1c7 \%以上者は3群間で差がなかった(表2)。

表 2 BMI別にみた神経症状の頻度と背景 （罹病期間10年未満者）

\begin{tabular}{l|ccc}
\hline \multicolumn{1}{c|}{ BMI } & 20未満 & $20 \sim 24$ & 24以上 \\
\multicolumn{1}{c|}{ 例 数 } & 95 & 376 & 269 \\
\hline 四肢の自覚症状 & $46.3^{*}$ & 32.2 & $39.8^{*}$ \\
自律神経症状 & 62.5 & 64.6 & 62.8 \\
仗リ治療者 & $33.7^{*}$ & 24.7 & 27.1 \\
$\mathrm{HbA1c \geqq 7 \%}$ & 15.8 & 13.0 & 16.4 \\
\hline${ }^{*} \mathrm{P} 00.05$
\end{tabular}

(3)振動覚異常者は、BMI24以上の群で $25.4 \%$ と 20〜24の群の15.8\%に比して高頻度であった。 MCV、SCVのいずれかが異常を示した伝導速度 異常者は、BMI20未満の群で $31.7 \%$ と20～24の 群の $14.2 \%$ に比して高頻度であった(表3)。

表 3 BMI別にみた神経機能異常者の頻度 (罹病期間10年未満者)

\begin{tabular}{l|ccc}
\hline BMI & 20未満 & $20 \sim 24$ & 24以上 \\
例数 & 41 & 183 & 130 \\
\hline CV $_{\mathrm{RR}}$ 異常者 & 9.8 & 18.6 & 16.2 \\
振動賞異常者 & 14.6 & 15.8 & $25.4^{*}$ \\
伝導速度異常者 & $31.7^{*}$ & 14.2 & 10.0 \\
\hline${ }^{*} \mathrm{P}<0.05 \mathrm{VS} \mathrm{BMI}$ & $20 \sim 24$ & & $(\%)$
\end{tabular}

【まとめ】やせ型や肥満者では標準体重者に 比して神経障害の頻度が高く、特に肥満者は 標準体重者との間に血糖コントロールや罹病期間、 治療法に差がないにも関わらず頻度が高かっ た。一方やせ型では似对治療者が多く、糖 㽷病の重症度が関与していると考えられた。 以上より、糖尿病性神経障害の発症と体型と の間には関連があり、適正な体重管理が重要 と思われた。 


\title{
運動器疾患
}

\section{$2 \mathrm{~F} 13$ 変形性膝関節症の悪化要因としての関節水種}

\author{
栗若 良臣、井上 和正、岡田 祐司、 \\ 宮武 慎、黑田 孝明 \\ 徳島県厚生連麻植協同病院 整形外科
}

\section{変形性膝関節症、関節水腫、活性酸素}

\section{【目的】}

変形性膝関節症は中高年層に多く発生する疾 患であるが、約 90\%は原因不明の一次性であ る。本症ではしばしば多量の関節液、いわゆる 「水」が貯留している場合があるが、この関節 水腫が本症にどのように影響を与えるかはほと んど述べられていない。また、実際の臨床の場 でも関節水腫を穿刺すべきかどうかについても 定説がないのが現状である。そこで今回、変形 性膝関節症の関節水腫を中心に調查し、悪化要 因与える影響について検討した。

\section{【方法・結果】}

1）初診後 9 年以上経過（平均経過年数は 10 年 5ヶ月）した変形性膝関節症例（男性 7 例 11 膝、女性 70 例 91 膝、計 77 例 102 滕）の関節水 腫の有無および性状について調查し、関節水腫 と本症の進行との関連を検討した。関節水腫の 既往がある症例に悪化例が多く、とくに関節液 中に白血球（ほとんどが好中球）が 1000 個 / $\mathrm{mm} 3$ 以上の症例では全例 $X$ 線分類で grade4 (終 末期）まで進行していた。

2 ) 関節水腫を有する变形性膝関節症患者の 関節液中に含まれる好中球を採取し、好中球の スーパーオキシド (活性酸素) 産生能を変形性 膝関節症患者の末梢血中に含まれる好中球と比 較した。

実験は、チトクロームC の還元法を用い、 スーパーオキシド産生能を産生初速度（nmol） $\mathrm{min} / 106$ cells)、と最大産生量 (nmol/106cells) をもって表した。
その結果 PMA 刺激、Zymosan 刺激共、スー パーオキシド産生初速度、最大産生量ともに 末梢血中の好中球と比較して関節液好中球の 方が有意に高い活性を示した。

3 ）関節液量と関節内圧、絨毛の血行との 関連を知るため生理食塩水を膝関節に注入し、 圧測定装置、顕微関節鏡を用いて各々調査し た。変形性膝関節症 31 例 31 関節、対象として 膝内障 56 例 56 関節について調べた。変形性膝 関節症例では $25 \mathrm{ml}$ の生理食塩水の注入で、滕 屈曲 60 度以上で絨毛血流は停止し、50mlでは 伸展位でもすでに血流は認められなかった。 したがって関節水腫が存在する膝関節では屈 伸に伴って絨毛血流が断続していると言える。 しかし座位などで長時間の屈曲後に膝を伸展 すると、一種の再環流障害（reperfusion syndrome）が惹起され、スーパーオキシドの 産生がさらに促進されることになる。つまり 2 ）の実験結果と同じ現象が起きることにな り関節軟骨に障害を与える。

今回得た結果より関節水腫は変形性膝関節 症の悪化要因となり得ると考えらた。 


\section{$2 \mathrm{~F} 14$ 人工膝関節の術後成績}

$\mathrm{JA}$ 新潟厚生連魚沼病院整形外科

村山信行、小林祥悟、朝長明敏、早稲田明生、 吉野匠

人工膝関節置換術、变形性膝関節症、慢性関節りウマチ

〔はじめに]変形性膝関節症（以下OA）お よび慢性関節リウマチ（以下R A）に対して 著者らが行った人工膝関節置換手術（以下 T K A ) の成績を報告し、術後の問題点と今後 の課題について検討する。

〔症例〕1991年10月から1995年 1 月までに当 科で行ったTKA32例42膝を対象とした。術 後経過期間は 6 力月から 3 年 8 力月、平均 2 年 1 力月である。性別は、女性28例37膝、男性 4 例 5 膝、手術時年齢は53歳から80歳で、こ のうち O A は男性 3 例 3 膝、女性21例26膝、 R A は女性 6 例 11 膝、男性 1 例 2 㯟である。 使用した人工関節は、Zimmer MGII34膝、 J\&J.PFC 5 膝、その他 3 膝である。膝蓋骨 は全例置換し、Tibial component 之膝蓋骨 に対してはcementを使用した。臨床成績の評 価は OA および $\mathrm{R}$ A膝治療成績判定基準（ OA）に従って判定し、X線所見と合併症に ついても検討した。

〔結果〕JOAscoreは全体では術前平均 37.5 点が66点に改善し、疾患別では、OAでは40.3 点が 71.6 点に、RAでは 31.2 点が 53.8 点に 改善した。可動域は $\mathrm{OA}$ A゙は $-18.4^{\circ} / 97.6^{\circ}$ か らー2.8 $/ 92.9^{\circ}$ 、同様に R A では $-26.9^{\circ} /$ $89.2^{\circ}$ からー $6.9^{\circ} / 84.6^{\circ}$ であった。特に改 善の著しかったのは疼痛と歩行能であった。 合併症としては特記すべきものはなかったが、 術前よりあ可動域の減少した症例が 8 例認め られた。重篤な合併症である感染やloosening はなかったが、1例が皮膚縫合糸膿瘍の処置
を行い、術後 3 年 6 力月経過した65歳の R A の女性にX 線写真上Clear zoneが見られた。

[考察] OApRAに対する人工膝関節手術 は以前は感染やlooseningの問題があったが、 無菌操作や材質の改良により現在では激減し ている。乙の度は術後平均 2 年 1 力月という 短期調查のため関節の破壊摩耗などは皆無で あったが、R A の 3 年 6 力月経過例にtibial componentに clear zoneがみられ、これら の注意深いfollowが必要と思われる。また、 今後の課題としてplasticの摩耗やloosening などに注意を払う必要があろう。本手術の最 大の利点は疼痛改善であり全例が満足してい る。RAでは術前の可動域を確保、または増 加した症例が77\%であったが、OAでは可動 域の減少した症例が見られた。OAの症例で 術後の拘縮の著しい症例は手術手技に問題が あると考えられる。即ち関節周辺組織の解離 が十分になされていなかったり fat padを温 存しなかった為に、拘縮を引き起こしたと考 えられる。われわれの手術対象亡なる農業従 事者にとってはしゃがみこみ動作や正座の獲 得が理想であり患者むこれを期待するが現状 では不可能であり、除痛と歩行能力の増大が 目標と思われる。 
○渡部 健、浦田士郎、矢崎 進、大脇義宏、山田高士 浜辺卓也、洪 淑貴、前田健博、稲坦善幸

愛知県 安城更生病院 整形外科

慢性関節リウマチ（RA）、追跡調査、増悪因子

平成元年に当科で治療していた慢性関節リ ウマチ（RA）患者168名の5年経過後の現状 を追跡調査し、症状の進行した患者の増覀因 子につき検討を加えた。

\section{【症例及び方法】}

平成元年、当科で登録した RA患者は clasical R A 98例, difinite R A 70 例合計168例で あった。平成6年調查時、当科で治療続行中の 症例 116例、死亡例 18 例、転院通院中の者 19 例、通院を止めた者7例、追跡不能の者8例で あった。

死亡例 18例の死亡時平均年齢は68.5歳(47〜 89 歳) 、 $\mathrm{RA}$ 平均䍜患年数は、13.6年 $(3 \sim 47$ 年）であった。死亡原因は、心疾患5例、感染 症4例、悪性新生物4例、脳血管障害3例、その 他2例であった。

引き続き当科で治療中の116例につき、 Steinblocker の class 分類で評価を行い5年前の 評価と比較した。class $1: 11$ 例、class $2: 72$ 例、class $3: 22$ 例、class $4: 11$ 例、であっ た。5年間でclassの改善したのが1例、classの進 行が21例に見られた。Class 1 が 2 になったの

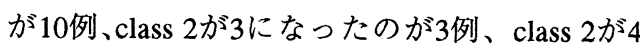
に、class 3が4になったのがそれぞれ4例であっ た。これらをclass $1 、 2 て ゙$ 変化のないものを及 びclass の改善したものを軽症 R A、class 3、4で 変化のないものを重症 R A 、 class 1、2から3、4に 進行したもの及びclass 3が4になったものを進 行 RAと分けた。それぞれの群の症例数は、 軽症 R A 群73例、重症 R A 群22例、進行 R A
群11例であった。

それぞれの群の平成元年度の検査所見及び 臨床症状、現在の投薬内容を比較し、 $\mathrm{t}$ 検定 にて統計処理を行った。

\section{【結果】}

軽症 R A 群と重症 R A 群では、CRP、ESR、 Hb、ARAの診断基準項目数,IgG,IgAに有意の 差が見られた。軽症 RA 群と進行 RA 群で は、CRP、ESR、診断基準項目数、IgG,IgMに 有意の差が見られた。CRPが5.0をESRが80を こえて、診断基準項目数が多く,IgG,IgMの高い 傾向が見られたたら，RAの進行が予測され るため積極的治療が求められる。

また、抗りウマチ郕は、軽症 R A の 63.4\%、 重症RAの $42.9 \%$ 、進行RAの $27.3 \%$ に使用さ れており、ステロイド剤は逆に軽症 R A の 22.5 \%、重症RAの57.1\%、進行RAの63.6\%に投 与されていた。

重症 R A 群、進行 R A 群、特に進行 R A 群 では、抗りウマチ剤の治療が奏効せず、ステ ロイドを投与せざるえない現状が示された。 
$2 \mathrm{~F} 16$ 橈骨遧位端骨折に続発した中指屈筋腱断裂の 1 例

带広厚生病院整形外科

○村村長三，倉上親治，福徳修治，小成幹久

木下淳, 渡辺裕樹

橈骨遠位端骨折，尺骨頭変形，深指屈筋腱断裂

樈骨遠位端骨折後に長母指伸筋腱断裂が続 発することはよく知られているが、屈笛腱断 裂が起こることは非常に稀である。今回我々

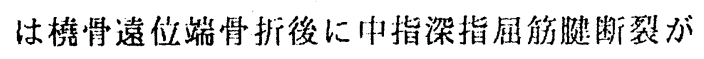
発生した症例を経験したので報告する。

【症例】71才、女性。平成 3 年 2 月に転倒し 左手をついて受傷した。他医にて左橈骨筤位 湍骨折の彰断で40日間のギプス周定を受け、 骨折は治疻した。平成 5 年頃より重い物を持 ったときに左手関節尺側部痛出見。平成 6 年 6 月に握ったとき左中指と左小指のD I P 関 節の㡽曲が恵いことに気づいた。平成 6 年 7 月当科初診。

初䧐時左手関節はディナー・フォーク様変 形を呈していた。在手関節掌尺侧部に軟性の 腫㢞があり、同部に爪痛を認めた。左中指 D I P 関節はＭＰ、ＰＩＰ関節が伸展時わず かに屈曲可能であったが、屈曲時には全く風 曲不能であった。左小指D I P 関節はM P、 P I P 関節が屈曲時、 $30^{\circ}$ の屈曲しかできな かった。X線写真では棪骨遠位端は背局位で 変形治瘾していた。尺骨遠位湍も変形し、掌 侧へ大きく突出していた。中指深指屈筋腱典 裂と小指深指屈筋腱㾍着を疑い手術を行った。 左手関節掌尺侧の腫旗部を切開すると中指・ 環指・小指の深指屈肪腱は肥厚した滑膜様組 織に包まれ一塊となっていた。その背侧には 腫㾍を押し上げるように変形した尺骨遠位端 が存在していた。この滑膜様組織を切除する と中指深指厥筋腱は完全に断裂していた。環
指と小指の深指屈筋腱は断裂はしていなかっ たが、摩耗し損鹪されていた。突出した尺骨 遠位端を切除し、㓷裂した山指深指屈筋腱の

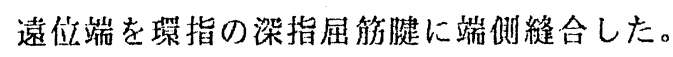
術後 5 か月、左中指D I P 関節の自動屈曲は 可能となったが、左小指D I P 関節の自動座 曲觕は変らない。

【考察】橈骨溒位湍骨折後に紿発する继䉼裂 のほとんどが伸秎腱断裂であり、屈筋腱断裂 が少ない理由は、權骨遠位端で伸䇨腱が直接 骨に接するのに对し、屈等腱は骨との間に方 形回内筋が存在するためと考えられている。

梲骨遠位端骨折後に続発した屈筋腱断裂例 のほとんどは变形治潦した㯲骨遠位端骨折部 の骨乫起との摩擦により起こっている。しか し、この症例では受傷洔骨折のなかった尺骨 遠位端が変形して腱断裂の原因となっており， この点でも興味深い症例である。 
香川県厚生連屋島総合病院检查部

○多田一美・畠由香里 - 細川春美 - 小西勉

[はじめに $]$

近年・予防医学の普及林よび抗結核剂の 発達により、肺結核の頻度は著しく減少し それとともに骨・関節結核もさらに少なく その罹患率は全結核病変の約 $1 \%$ といわれ ている。しかもその半数以上は脊椎力リエ スであり、その他の骨・関節結核はきわめ て希である。

そのような中で今回私達は、結核既往の ない患者に手関節結核性滑膜炎を経験した ので報告する。

\section{[症例] 80 歳 女性}

[主訴］右手背部腫張

[垷病歴]

結核の既往、家族歴なし。

1994 年 5 月頃より右手背部の腫脹を 訴え、某医にて関節リウマチと䛦断され、 切開術を受けたが改善せず、しだいに腫張 が増悪し、同年 10 月当整形外科を受診し た。

\section{[臨床検查所見]}

W B C $6800 / \mu 1$

C R P $1+(0 \cdot 5 \mathrm{mg} / \mathrm{d} \mathrm{l})$

血沈 $75 \mathrm{~mm} / 1 \mathrm{~h}$

ツ反 $35 \times 25 \mathrm{~mm}$

\section{[臨床経過］}

受診時の腫癔穿刺液による結核菌の塗抹 培養検查は陰性であったが、滑膜切開術、 施行時の滑膜生検にてL a n g h a n s 巨細胞をともなう肉芽腫の形成がみられ、
結核性病変が示唆された。

創部の組織片を擦過し抗酸性染色を行った ところ、ガフキー5 号が観察された。又、 組織片の培養の結果、 2 週間後に $2 \%$ 小川 培地に抗酸菌の発育が認められた。本菌は D N A プローブ法にて結核菌群と同定され その後の生化学的性状により、人型結核菌 であることが確認された。

しかし、喀痰の塗抹・培盖・P C R 法に よる抗酸菌の確認はいず扎も陰性であり、 全身 C T、M R I 、超音波検查にても他蔵 器、組織に結核病変を疑わせる所見は認め られなかった。

現在、 $1 \mathrm{NH} 、 \mathrm{KPF} 、 \mathrm{E} B 、 の$ 抗結核 剤により入院加療中である。

[考察]

骨・関節結核は日常遭遇することは少な いが、最近は見逃しや診断の遅れによる、 進行例の増加が指摘されている。

今回の症例は早期に結核性と診断できた 手関節滑膜炎の希な症例であると考えられ た。 


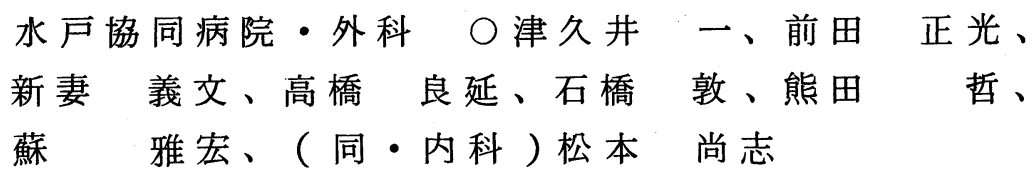

\section{横较筋融解 症、D.I.C}

〔はじめに〕横絞筋融解症は、骨格筋の融 解・壊死によって笳細胞成分が遊出する病態 である。原因は外傷のほか多岐にわたり、外 傷性・非外傷性に大別される。近年、非外傷 性のものの報告が相次ぎ稀な疾患ではなくな ったが、疾患を理解し、多臓器不全に至るま えの初期の適切な治療が必要である。今回汎 発性血管内凝固症候群（D.I.C）を合併した が血液透析を要さなかったマランンによるも の、アルコール飲酒によるもの各 1 例を経験 したので臨床経過を中心に報告する。

〔症例〕症例 1 （外傷性）18 才高校生、 校内 $10 \mathrm{~km}$ 走のゴール直前「目の前が真白く なり」意識消失、体温 $40.2{ }^{\circ} \mathrm{C}$ 、発汗 $(+)$ 、血 圧 $150 / 80 \mathrm{~mm} \mathrm{Hg}$ 脈拍数 $180 /$ 分呼吸切迫、 脱水、過換気症候群で初期治療。全身けいれ ん、意識障害の改善がなく、第 3 次救急病院 （脳神経外科）に搬送。脳浮腫なし、約 4 時 間で意識レベル、筋強直な改善す。 48 時間 後帰宅した。両下肢の痛みを訴えたが腫張な く自力歩行可能であった。「熱中症」と診断。 静脈ラインの皮下血腫あり CPK 異常高值、 血小板数の減少を認め当日再入院、D. I.C の治療を行なう。C PKの再上昇が発症10日 にあり second wave phenomenonを呈し た。

症例 2（非外傷性、アルコール飲酒）74才 男、 1 年 5 ケ月前胸部食道癌手術。来院 10 日前より食欲不振、下痢この間飲酒は続け 8 升を飲んでいた。全身筋力低下・歩行不能、
末稍循環障害を認めた。D. I. C合併、原因不 明の感染症を呈す。2 症例とも腎機能障害を 認めたが血液透析を要さず。D. I. C 治療はへ パリンとA T III製剤であった。（表 1 ）

〔考案〕表 2 にホオグロヒン尿症の簡便な 鑑別を示す。 2 症例とも尿潜血反応強陽性で あったが尿沈渣では赤血球数 1 〜 5 ケ視野。 原因となるべき誘因をさぐりつ〉筋由来逸脱 酵素の測定および血・尿中ミオグロビンの検 出で診断される。D.I.Cをはじめ多蔵器障害 を合併すると現在でも死亡例もあり早期の適 切な治療が必要である。横絞筋融解症の原因 は古くから指摘されている原因のほか、近年 積極的に治療の対象となっている高脂血症治 療薬のなかに重篤な本症例が報告されている ので多岐にわたる非外傷性の横絞筋融解症が 存在することに改めて留意したいと考え報告 した。

\begin{tabular}{|c|c|c|}
\hline & 症 例 1 & 症 例 2 \\
\hline & 18才 男 & 74才 男 \\
\hline 誘 因： & $10 \mathrm{~km}$ 走 & アルコール \\
\hline $\mathrm{CPK}(\mathrm{IU} / \ell)$ & 87.822 & 11.100 \\
\hline $\mathrm{S}-\mathrm{Mb}(\mathrm{ng} / \mathrm{m} \ell)$ & $500 \uparrow$ & $500 \uparrow$ \\
\hline $\mathrm{BUN} / \mathrm{C} \mathrm{r}(\mathrm{mg} / \mathrm{d} \ell)$ & $30 / 2.52$ & $95 / 2.85$ \\
\hline 血小板数（mm"） & $3.2 \times 10^{4}$ & 3. $3 \times 10^{4}$ \\
\hline $\mathrm{AT} \mathrm{III}(\mathrm{mg} / \mathrm{d} \ell)$ & 20.8 & 10.3 \\
\hline 合併唗 ： & D. I. C & D. I. C \\
\hline 透 析： & $(-)$ & $(-)$ \\
\hline 予 後： & 良 & 良 \\
\hline
\end{tabular}

表 2 ミオグロビン尿症の鑑別

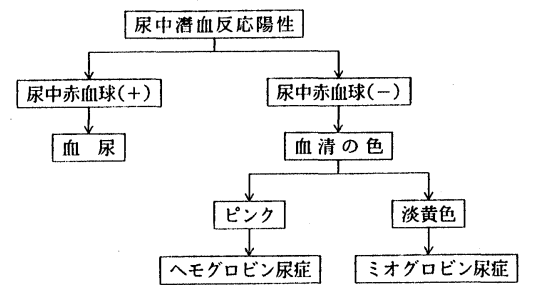


2F19上腕二頭筋長頭腱皮下断裂

加茂病院 整形外科

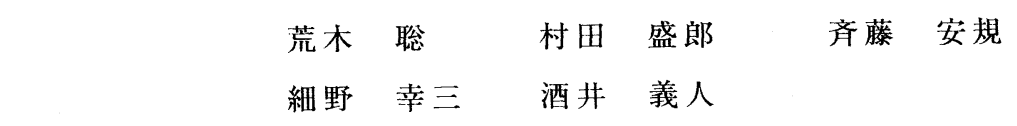

上腕二頭筋腱断裂保存療法

上腕二頭筋長頭腱皮下断裂は、国外ではそ の報告は少なくない。しかし本邦では内藤に より初めて報告されて以来その報告例は意外 に少ない。またその治療法に関しては観血的 治療を薦める意見が多いが、保存的治療を薦 める論文もあり意見の分かれるところである。 著者は最近 10 年間に 13 例の上腕二頭筋長頭 腱皮下断裂を経験し、治療は数日から数週の 対症療法にとどめ、その後放置経過観察とし てきた。これらを若干の考察を加えて報告す る。

初診時所見

主訴肩挙上時に肩関節部の痛みがある、 違和感があるなど軽症の肩関節周囲炎の症状 がほとんどである。一部の例で上肢の筋力低 下、上腕部屈側の異常腫瘤を訴えて受診して いる。

$\mathrm{x}$ 線 老人例が多いため上腕骨大結節部 の硬化像、肩峰下面の骨棘形成など変形性関 節症の所見が多い。また上腕二頭筋長頭腱断 裂に先行して生じていると考えられる肩腱板 損傷を疑わせる肩峰下臆の狭小化が多くにみ られる。

職業歴 長期間のストレスにより上腕二 頭筋長頭腱に変性、断裂が生ずると考えられ ているように、長年月の間農業、工業などの 肉体労㗢に従事している例が多い。また発症 はほとんどの例で利き手側の右肩の発症であ る。

診断时屈曲位で力を入れさせた時、上
腕二頭筋筋腹が異常に末梢に移動してみられ れば本断裂であり診断は容易である。しかし 肩周辺の圧痛、可動域などにはこの疾患の特 徵は特にみられず、この疾患の存在を念頭に おき診察に当たる必要がある。

症例

経験症例は 10 年間で 13 例であり、性別は 男 10 例、女 3 例と男に多く、年齢は 41 歳から 86 歳までの平均 67 歳で全例中高年齢層であっ た。左右別では右が 12 例、左が 1 例と圧倒的 に右側損傷例が多かった。職業別では 11 例が 農業で、残る2例も機械工として働き、休日に は農業に従事していた。発症機転としては、 9 例は特に誘因なく発症していた。また機転 はっきりしていた 4 例はいずれも軽微な外傷に よるものであった。

治療治療は2週間程度の外用薬などによる 対症療法のみに止め、その後は放置経過観察 した。

予後予後は、 2 ケから 5 年の経過観察で 全例何らかの肩の違和感、軽度筋力低下を感 ていたが、健側との差もわずかで、何ら支障 く日常生活を送っており、経過良好であった 結語

著者は過去 10 年間に 13 例の上腕二頭筋長浢 腱皮下断裂を経験し、治療はすべて放置経過 察としたが、特に日常生活に支障なく、予後 良好であった。壮年以降の本断裂に対する治 は放置が最善の方法だと考えている。 


\title{
2 F20 農村の肩関節疾患
}

○保坂正人, 町田拓也, 山崎郁哉,

伊東秀博, 下形光彦, 伊藤仁 (長野・佐久総合病院)

\begin{abstract}
Impingement syndrome（インピンジメント症候群）， Rotator cuff（腱板）, Frozen shoulder (五十肩)
\end{abstract}

【目的】われわれの地域は農作業に従事する 中高年の労働者が多い農村地帯である.今回， 肩関節疾患を調查対象として疾患別の分類を 行い当地域における特徵を検討した。

【対象および方法】過去 3 年間に肩関節疾患で 外来を受診した618例を対象とした。疾患の分 類では以下の点に注意した。疼痛と挙上制限 を主訴とする肩関節疾患のうち, 五十肩は拘 縮が存在する狭義の五十肩に限った。一方， 拘縮を伴わず肩峰下のインピンジメント徵候 を認める場合はインピンジメント症候群とし た。

【結果】疾患別で最も多かったのはインピン ジメント症候群で228例 (平均58.3才)であった。 次いで五十肩が96例 (平均59.5 才), 腱板断裂 が84例 (平均63.6才)であった。インピンジメ ント症候群の内, 症状が遷延して経過中に画 像診断などで腱板断裂に訂正した症例が25例 ありこれらを加えると腱板断裂は109例で五 十肩を上回った。以下, 石灰性腱炎は58例 (平 均53.4才), 骨折は 43 例 (平均 48.9 才), 脱臼は 30 例 (平均 47.7 才), 変形性肩関節症は 12 例 (平均69.8才), 上腕二頭筋長頭腱炎は 10 例 (平 均 49.8 才), 腱板疎部損傷は8例 (平均22.0才), 滑液包炎は6例 (平均 65.0 才), 末梢神経障害は 6 例 (平均38.3才), 肩関節不安定症6例 (平均 15.0才)，慢性関節リウマチは5例 (平均 63.2 才), 関節唇損傷 4 例 (平均 31.5 才), 腫瘍 3 例 (平均 59.0才)であった。挫傷や診断のつかない肩痛 は19例 (平均47.0才)あった。
患者の職業別の内訳では, インピンジメン 卜症候群と腱板断裂は農業従事者とその他の 労㗢者に多く, 五十肩は軽作業者や整形外科 以外の疾患で長期療養中の患者に多く見られ た。石灰性腱炎は職業別で特徵は見られなか ったが，他の主な疾患と異なり女性 45 例に対 し男性13例と女性に多く見られた。

明らかな外傷に起因したものはインピンジ メント症候群と五十肩では20\%以下であり, 腱

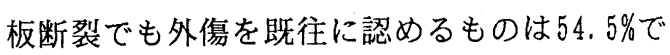
あった．石灰性腱炎では全て外傷機転を欠い ていた.

【考察】中高年者の肩関節疾患は年令の特徵 から安易に五十肩と呼ばれることが多い。し かし詳細に検討すると，50才前後に発症して 疼痛と関節拘縮を主症状とする狭義の五十肩 はそれほど多くはない. Neer は impingement syndrome を提唱し腱板の急性外傷性の障害 から変性性断裂までを説明した。われわれが 日常診療でしばしば遭遇する中高年者の拘縮 を伴わない肩関節周囲炎の多くは Neer の impingement syndrome の stage IIまたは stage IIIに相当するものと考えられる.

われわれの施設は高齢の労働者が多い地域 に立地する特徵があり, 加秢と酷使によって stage の進んだ impingement syndrome が多いこ とが予想された。今回の調査により当地域に は肩インピンジメント症候群の患者が多く, その中には stage の進んだ腱板断裂も相当数 存在することが明かとなった。 


\section{F21 鎖骨遠位端骨折の治療成績}

畠野宏史、安川敬一郎、玉木満智雄 水井伸子、長谷川淳一 長岡中央綜合病院整形外科

鎖骨遠位端骨折、転位率、治療成績

【はじめに】一般に鎖骨骨折は保存療法でよ く骨癒合し機能的予後も良好で手術適応は少 ない。しかし、鎖骨遠位端の骨折の中には、 保存療法では骨癒合を得られない症例がある。 今回我々は鎖骨遠位端骨折の手術適応につい て検討したので報告する。

【対象と方法】症例は平成 2 年10月から平成 7 年 5 月までに当科で加療した鎖骨骨折 166 例のうち鎖骨遠位端骨折22例（13.3\%）であ る。症例の内訳は、男性10例、女性12例で、 受傷時年令は 18 -78才（平均47才）であった。 受傷原因は交通事故による転倒が最も多く11 例であった。骨折型はNeerの分類 (1984)に 従う之、type 1 が 4 例、type 2 が17例、type 3 が 1 例であった。Neer 分類では骨折部の転 位度については言及されていないため、我々 は単純 X線前後像から骨折部の転位率を算出 し、転位率之骨癒合の関係を retrospectiveに 調査した。症例を転位率 $50 \%$ 未満と $50 \%$ 以上 の 2 群に分けて、この 2 群間で骨折の形態、 骨癒合、機能予後を比較検討した。また手術 症例は 9 例で、全例転位度 $50 \%$ 以上のtype 2 であり、キルシュナー鋼線 (K-wire) による 固定術を施行したが、これらの症例でのK-wire 刺入部位の検討を行った。

【結果】転位率50\%未満の13症例では、骨折 形態はすべて斜骨折であった。全例 8 字帯固 定による保存療法を施行した。13例中 1 例で 骨癒合が得られなかったが、痛みや機能障害 はなく、最終的な治療成績は全例良好であっ
た。転位率50\%以上の 9 例中 4 例は縦骨折で あり、縦骨折では転位率が大きくなる傾向が あった。手術は 9 例中 6 例に新鮮時に施行し、 骨癒合、機能予後とあに良好であった。他の 3 例は新鮮時に手術されず骨癒合が不良であ ったため後に手術したが、術後成績は良好で あった。次にK-wire刺入部位について検討し た。K-wireを 2 本とも肩峰から刺入した 5 例 中 2 例で骨折部の転位、2 例でK-wire のゆる みが生じ、そのうち転位した 1 例に再手術を 施行した。鎖骨遠位端から刺入した症例では 術後経過で問題はなかった。

【考察】Neerは鎖骨遠位端骨折で鳥口鎖骨 靶帯損傷のため転位のあるtype 2 を手術適応 としている。しかし、type 2 であ骨折部の接 触面積がある程度保たれた転位の小さい症例 では、骨性の癒合が得られ機能予後む良好な 場合がある。今回の retrospectiveな調査で は、転位率が50\%未満の症例は保存療法で成 績は良好であった。転位率が50\%以上の症例 の場合、保存療法では骨癒合不良で、手術適 応ありと考えられた。骨折形態に関しては縦 骨折は斜骨折より転位し易く、手術適応にな り易い傾向があった。手術でのK-wire刺入 部位は、肩峰よりも鎖骨遠位端で骨癒合が良 好であった。乙れは肩峰から刺入した場合、 肩峰之鎖骨の解剖学的関係からK-wireの骨 折部位への刺入が短くなり不安定になりやす いためと考えられた。 
2F22 老人の大腿骨頝部骨折——宮坂氏ピンの使用経験

$\begin{array}{llllll}\text { 愛全病院 : 小森 } & \text { 吉夫 } & \text { 小野 } & \text { 勝代 富永 淳 } \\ \text { 北新病院 : 広田 誼 } & \text { 菊田丰彦 } & & \end{array}$

老人が寝たきりになる原因として、心肺 機能の低下・主疾患の增悪に上る全身衰弱 と共に大腿骨頝部骨折がある。当院は、平 均年齢 80.9 歳の老人 650 人を収容し 入院医療管理料（工）型を標榜している介 護力強化病院である。主疾患として脳血管 障害69.7\%他心㶼患・高血正が多い。 又、表の如く"ぼけ”がない方は、僅か 1 4. 3\%にすぎない。脳活性化、リハビリ、 プレ・フラクチャー・ケアを 3 本柱として 看護・介護に努好裖創駆除には成功したも のの、年齢と共に増悪するデメンツと大腿 骨頝部骨折の発生を押さえこむことは不可 能であった。骨折が発生した時には、関連 病院で手術して頂き帰院後早期リハビリ及 び看護に努力して来たが主疾患・痴呆の増 悪をみることもあり、転医先の病院ス夕ッ フとのコミュニケーション不良により思わ 如トラブルを発生することもあった。手術 はC．H．S．や人工関節置換か殆んどで、 麻酔や大きな侵襲のせいか不幸な転機をと
る方もあった。

当院では、昨年より宮故氏ピンを施行し、 その数も2 5 例を超えたので反省・考察を加 え報告する。骨折発生後直ちにリ八病棟に移 し、鋼線牽引を行い、各種梌查を進奴つナ 一ス、ワーカー、P. T. とコミュニケート を深め、1 n h o r m ed Consent を充分にとった後手術を行った。手術はコミ ュニケートのとれたナース、ワーカーを患者 の枕頭におき会話をとりつつ局麻、レ線透視 下に宮坟氏ピンにて固定した。術前より $1 \mathrm{~s}$ ometric Exercise在指導し てきたP．T、により術装日より”リハビリ” を継続し、体交・坐居も恐柨感を起こさぬ様 充分気配りしながら進めた。術後10日前後 で車椅子乗降を指導し、拔糸後は渦流浴を勧 めた。患者の充分な看視之温かい介助により 心・身共に良好に復帰することが出来た。比 較的若年者之老人に発生した大腿骨频部骨折 者の骨塩定量の成績と宮坂氏ピン施行症例を 供覧する。

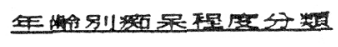

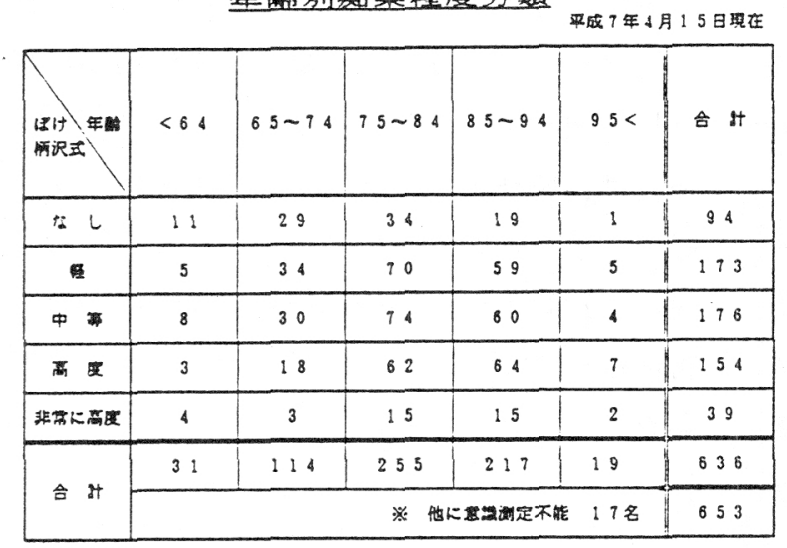

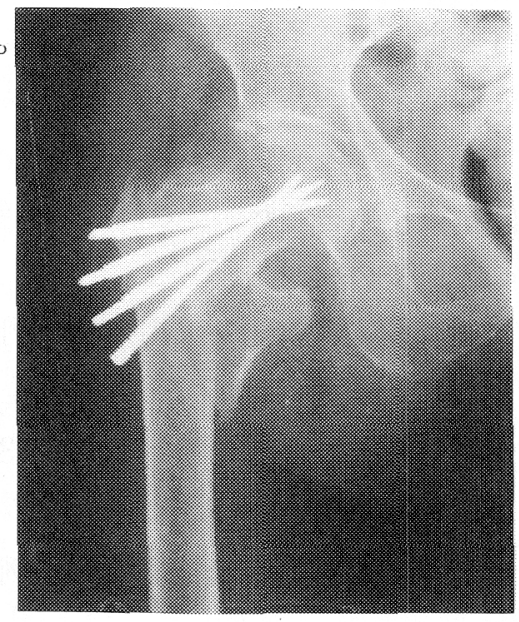


佐渡厚生連佐渡総合病院 整形外科

松枝 宗則 石井 義則 八木沢克則

\section{大腿骨頚部骨折生命予後疾呆}

平均寿命を越えた 85 歳以上の超高齢者の大 腿骨䅡部骨折患者について検討し、退院時步 行能力と生命予後の関係、およびこれまで痴 呆のあるなしといった定性的評価が大部分で あった痴呆の定量的評価を行い、調査時の歩 行能力との関係について検討した。

対象と方法: 対象は平成 2 年 4 月より平成 7 年 3 月までの 5 年間に観血的治療を行った 178 例 中49症例で、全体の $28 \%$ あった。性別は男 10 例、女 39 例、年齡は 85 歳から 101 歳、平 均 88.3 歳であった。経過観察期間は 1 力か ら 4 年 10 力月で、平均 1 年 6 力月であった。歩 行能力に応じて自力歩行可 (自)、介助歩行可 （介）、寝たきり（寝）の3群に分類した。生命 予後を調査するため、上田ら ${ }^{1)}$ の方法に準じて 余命見込みの計算をした。死亡例は手術から 死亡までの期間を余命とした。生存例は、手 術から調査時までの期間に、（自）(介）には 平均余命期間をまた（寝）には平均余命の 1 ／ 2 を加えた。

症例の概要 : 1) 骨折型と治療法 骨折型は内 側型が 11 例、外側型が 39 例で、早期離床を目 的とし、全例に観血的治療が行われた。

2) 合併症痴呆 $58 \%$ 、循環器疾患 $56 \%$ 、低 蛋白血症 $56 \%$ 、貧血 $54 \%$ な゙゙が高頻度に見ら れた。

3) 死亡例の内訳 調査時死亡例は 24 例 $48 \%$ であり、死亡までの期間は 1 力月から 4 年 10 力月、平均 1 年 3 力月であった。死亡原因は、 老衰 13 例、肺炎 5 例、心不全 4 例、脳梗塞 1
例、胆囊炎 1 例であった。

4) 歩行能力 生存例で、退院時自力歩行能力 を再獲得したのは 22 例中 16 例 $73 \%$ 、死亡例 で退院時自力歩行可であったのは 17 例中 7 例 $41 \%$ 、生存例とは大きな差が見られた。

結果および考察 : 1) 退院時歩行能力と生命予 後 見込み余命は退院時 (自) の群は 4.61 年 （介）の群は 2.56 年、(寝) の群は 1.45 年亡明 らかに歩行能力により見込み余命に差が見ら れ、退院時歩行能力が生命予後に影響を与え ていると考えられた。なお、全体の手術時平 均余命期間は 4.55 年であった。

2) 調査時歩行能力之痴呆之の関係 生存例の 26 例に長谷川式痴呆スケール、また欧米で主 に痴呆スコアリングに用いられる Mini mental - state testを行い痴呆の程度を調 査した。(それぞれ 30 点満点）それぞれ平均 は、（自）が 20 点と 22 点、(介）が 15 点と 18 点、(寝) が 4 点と 6 点で、検定の結果、調査 時歩行能力との間に相関関係が見られた。 まとめ

1）退院時歩行能力が、生命予後に影響を与え ていると考えられた。

2) 痴呆の定量的評価を行い歩行能力との間に、 相関関係が見られた。

参考文献 : 1) 上田 淳他.90歳以上の大腿骨 頝部骨折の治療成績.骨折 $1993 ; 15$ (2) : 87 $-92$ 
2F24 小児環軸椎回旋性固定の5例

○坂田和之、武田修一、㴊岡道行、元島謙司、川村憲史、増田 等 (総合病院 取手協同病院整形外科)

環軸椎回旋性固定 (Atlanto-axial rotatory fixation)

\section{【目的】}

小児において上気道感染や小外傷などの誘 因によっておこる斜頚については様々な名称 が使われてきたが、1977年Fielding以来atla nto-axial-rotatory fixation（環軸椎回旋 性固定：以下AARFと略す）という名称が広く 用いられている。今回我々は、AARFを 5 例経 験したので臨床的検討を行い、若干の文献的 考察を加えて報告する。

\section{【対象と方法】}

当科にて過去 3 年間、臨床所見およびX線 所見よりAARFと診断した症例は 5 例である。 その内訳は、男 3 例、女 2 例で年齢は 5 才よ り10才、平均 6 才である。

方法として

1) 誘因

2)臨床的所見

3) X 線学的所見

4) 発症から治療開始までの期間

5)治療成績

に関して病歷、レントゲン写真を調査検討 した。

\section{【結果】}

1)臨床症状：全例にcock-robin-position といわれる特徵的斜頚位、頚 ・項部痛および 回旋反対側への著明な運動制限を認めた。し かし、神経脱落症状をみた例はなかった。

2) X 線所見とCT像：正面開口位像で歯突起 と環椎側塊との左右非対称性が全例に認めら れ、側面像では 2 例に環椎歯突起間距離（以
下ADIと略す）が拡大し、環椎の前方亜脱臼 を認めた。CT像に関しては、回旋角度 平均 $8^{\circ}$ でFielding分類に従うとFielding 1 型 3 例、Fielding 2 型 2 例であった。

3) 治療及び治療成績 : 発症原因を検討する と、なわとびや寝ちがえなどの小外傷 2 例、 頝部リンパ節腫脹や発熱などの感染後 3 例で あった。発症から初診までの期間は、1日か ら 3 週である。全例保存的治療を行い初期に はグリソン係蹄による持続牽引を施行し、疼 痛が消失・運動制限が軽快した段階で頝椎力 ラー装着した。牽引期間は、4 日から 2 週、 頚椎力ラ一装着期間は 4 週から 8 週である。 治療後、外見上变形もなく、X線上環軸関節 の左右非対称も消失した。

\section{【考察】}

我々の症例のうち、頚部痛・斜頚位が改善 されたにもかかわらず、X線・CT上しばらく 变形が残っていた症例が 1 例あった。その症 例は、他と比べて発症から初診までの期間が 3 週と長かった。文献的にも、発症から初診 までの期間が 3 週以内の場合、それ以上の例 と比較し治療成績が良好であった。以上より 治療成績は、早期の診断治療がきわめて重要 であると判断される。 


\section{$2 \mathrm{~F} 25$ 遊離組織移植により修復し得た 2 症例}

\section{大分県厚生連鶴見病院形成外科合葍英治 \\ 整形外科八塚知二}

\section{遊離組織移植、難治性潰滨、マイクロサージェリー}

深部組織が露出した症例や血行が悪い瘕痕 部潰瘍の症例などの修復は、しばしば困難で 難治性となることが多い。今回、外傷後に骨 折し、脛骨が露出した症例、また、大腿切断 端部の瘢痕性難治性潰瘍の 2 症例に対して、 遊離血管柄付き組織移植を行ない、良好な結 果を得たので若干の知見と考察を加え述べる。

症例 1 は、 6 藏男性、石とコンクリートとに挟 まれて受傷。受傷日、デブリードマン、骨接合、 人工皮虞による創閉鎖を行なったが、経過中、骨 髄炎を併発したので、血行の良好な筋皮弁による 創閉鎖を計画した。受傷から17日目、創外固定及 び広背筋皮弁による遊離複合組織移植術を施行し た。皮弁は完全生着し、創も完全閉鎖し、骨髄炎 も寛解した。

症例 2 は、 62 歳男性、右大腿切断端部に深い 潰瘍を形成した症例で、過去にも数回の再発を認 める。初診時、右大腿切断端部の内側に $7 \times 4$ cmの深い潰瘍を認める。前外側大腿皮弁による 遊離組織移植術を施行した。皮弁は、完全生着し、 創閉鎖も完了した。

考察

症例 1 の問題点として、6 歳で、骨髄炎の合併、 血管系の損傷、広範囲な皮膚欠損や骨露出等を考 慮すれば、血行の良好な有茎皮弁を第一選択に考 えたいが、実際には、困難である。そこで、年令、 損傷範囲、合併症、体位等を総合的に考慮して、 広背筋皮弁による遊離組織移植術を計画した。
症例 2 では、 62 歳で、糖尿病、貿血の合併、血 管造影所見、潰瘍の再発等が挙げられる。潰瘍の 部位、再発の点からも十分な血行のある皮弁を用 いたかったので左大腿前外側皮弁による遊離組織 移植術を計画した。

一般的な遊離移植術の適応と問題点を表 1 に示 す。また、ドナーの選択として、表 2 に示すよう に、遊離皮弁、遊離筋皮弁や筋弁、遊離骨皮弁等 が挙げられる。

今回、深部組織の露出した症例と難治性皮虚潰 瘍の 2 症例に対し、遊離組織移植術を施行し、良 好な結果を得たので報告した。

表 1 遊離組織移植の適応都問題点

適応 1 : 広範囲の皮膚及び軟部組織欠損

2 : 骨、腱、神経及び血管の露出

3 : 感染創や血行不全部位に筋皮弁

$4:$ 死腔の充填

問題点 $1:$ 患部の血管の有無

2 : ドナーの選択

$3:$ 年令

4 : 基礎疾患（糖尿病、動脈硬化等）

$5:$ 手術時間

6 ; マイクロの道具と専門医

表 2 ドナーの選択（遊離皮弁の種類）之問題点 患部の部位、状態、条件により選択

1 : 皮弁

頭皮弁、肩甲皮弁、前腕皮弁

単径皮弁、大腿皮弁、足背皮弁等

2 : 筋弁、筋皮弁

広背筋皮弁、大胸筋皮弁、腹直筋皮弁 大殿筋皮弁、薄筋弁等

3：骨皮弁 腓骨、腸骨、助骨、

4 : 遊離大網移植、遊離腸管移植

5 : 趾移植 


\section{リハビリテーション}

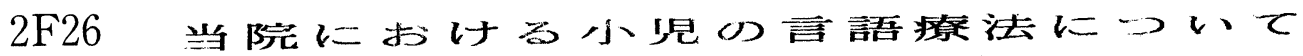

\section{$\mathrm{J} \mathrm{A}$ 愛知厚生連 渥美病院 \\ 理学診療科言語療法室 ○川口由香 杉原由美 小児科 我谷圭吾 永井美勢穂 松本延男}

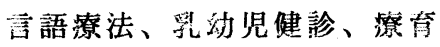

【目的よ小児の語について家族が問題視し 始めるのが $2 \sim 3$ 歳ごろであるが、この前後

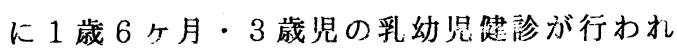
ており、その時点でどのくらいの子供たちが 問題点として言語のチェックを受けているの かを、今回渥美郡 3 町と保健所の保健婦に協 力を依賴し調查した。又、それを踏まえ、当 院に言語療法を受診した子供たちの実態と照 らし合わせながら、郡部における中核病院が 担う療公八の関わ方を考察する。

【対象】橴美郡 3 明において、些成 4 年度一

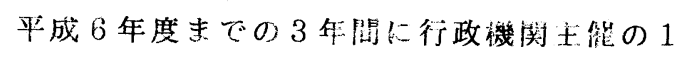

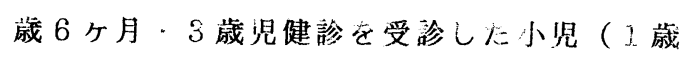
6 ケ月は 2185 名、3歳は 2016 名、受 診率はいずれも $90 \%$ 以上）上、当院で平成

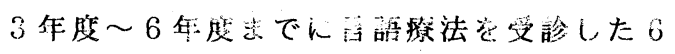
3 名の小児。

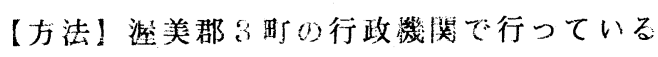
1 歳 6 ヶ月・3歲児の健診で使用している受 診状洗の用峨の方䊅をもとに、各年龄におけ る閶題の推移、言語あるいは言語に関係の深 い精神・聴覚の開題の占める割合、更に宫語 の和どのような内率の閣题がするのかを調 ヘ、、当院を受診した子供たちの筣のそれと 比慗する。

【絬果・考然】1藏6ヶ月児健診において問 題ありとさ机た头人数は受診者の $25 \%$ 。問 題ありとされ态項目の延心゙人数のけで占める 割合の多いのが、発達・機能の障害、次いだ

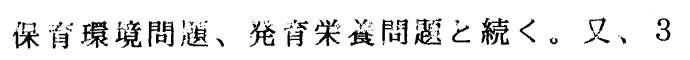

歳児健診においては、問題晾りとさ放た头人 数は $30 \%$ に昇り、問題ありとされる項目の 順位は 1 歳 5 ヶ月児とほぼ変化はないものの、

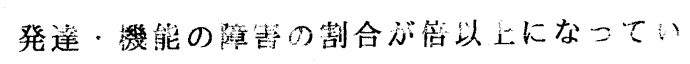
る。言語や言言と関係の深い䞍神・聴门とい つた欄がこの項目に含ま沈ている。特に言語 の割合は、 3 減児になると 1 歲 6 ケ月児の 3 倍になっている。

当院言語㙩法空にお行る初診時年秢の分布 見ると5歳、8歳、2歳が多く、就学已意

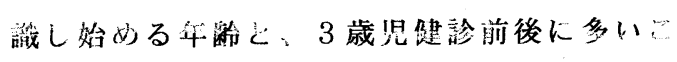
とが分かる。类躒に、受診のきっかけを尋わ ると、乳幻照健診での保健婦からの指摘であ

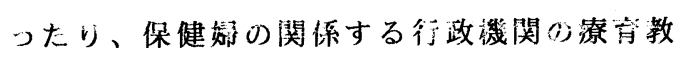
室からの情報だったりしている。又、初診法 年齢は等: 々低下の傾向にあり、以䏚は余程気 にならない限り尃門機関を訪称ることない自 宅で経過完罢ていたケースが、近くに受診出 来るとこるが出来たため、氛整に、むるいは 卓期に破㵳するようになってきたのではない かと考え絖る。

行政レベルからは比较的早期に言語に関し ての指摘がなされているにも関わらず、矵部 においては療育を行う機関（特に施設）が設 置されていることは稀で、遠方まで時間と費 用堂かけて出向かなければならない。このよ うな現状を考えると、郡部における骇病防 が、地示行政機関との関わり方を考慮しな分 ら療消の一端を担うことは地域のためにも大 きな意義を持つことと考穴れる。 
2 F27 初期の縅黙状熊からのちに混合型照皮質性失語在呈した一症例

○清水 篤 和田範文 岩越 優 森井幸一 西岡幸絵 田中 豊

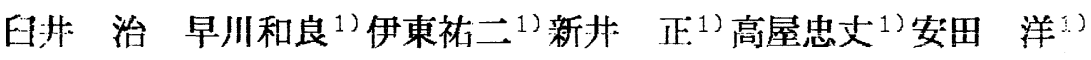

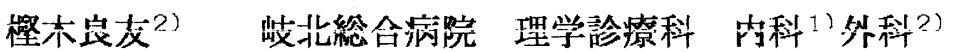

\section{悢照状態 復唱能力混合型超农質尘失語 \\ 【はじめに】}

今回我々は左大䏚半球の広範囲梗塞により 混合型超皮質性失語を呈した症例を経験した ので報告する。

\section{【症例】}

67 歳, 女性, 右利き, 高等小学校卒業, 農業及び家事手伝い。

\section{【現病歴・入院後経通】}

94 年 6 月 16 日見当識障害・右手のしびれを 主訴として入院。入院後約 2 日で右上肢・下 肢の麻㾇が進行, 意識レベルは入院時より变 化を認めなかった。その後18日間程は覚醒し ているのにもかかわらず䅉言であり，絨䓡の 状態が続いた。

\section{【画像所見】}

94年 7月31日の頭部CTでは, 角回・縁上 回を含む頭頂葉, 湖頭葉, さらに前頭葉, 基 底核, 内包の一部に低吸収域を認めた。

【神経学的所見】( 94 年 7 月）

意識は清明, 課題に対し集中力・持続力を 保持，礼節は保たれていた。光ん下障害・構 音障害はごく軽度，右上肢・下肢に中等度の 麻璅を喼めた。

【神経心理学的所見】( 94 年 7 月)

失語症，右半湖空間失認（のちに軽減）， 計算障害, 構成失行, 口部顔面失行, 観念運 動失行，観念失行がみられた。

\section{【言語症状】}

発症 3 䓢間後より復唱が可能となる。自発 語は乏しく反響言語での受笛答えとなった。
また，言語および動作にても保続傾问が強か った。

4 週間後に実施できた標準失語症検査では 睠く・話す・読む・書くといった言語能力の 全般に重度な低下がみられたが, 復唱能力は 保たれており全失語とは異なる症状を示して いた。他に，系列語・歌唱等は開始介助によ り促通され，淁などの慣用句で補完現象もみ られた。退院前に行った標準失語症涘査（発 症より 3 か月半後) では聼覚理解および読字 理解での改善が記められたものの初回検査時 と同様な傾向を残しており，意志疎通の為の 手段は限られたものであった。

【考察・まとめ】

Golds te in (1948) ${ }^{11}$ は, 復唱のみが良好に 保たれ，他の言語機能のすべてに重度の低下 を来す混合型超皮質性失語を，言語野坬立と して最初に記述した。以降 Geschwindら (19 68) 2) による言語野现立症候群の報告から， 今日までに成された報告は少なく, C T 等に より病巣が明らかなものはさらに少ない。

本例も入完後経過, 言語症状，画像診断等 の結果より，失語症としては稀な混合型超皮 質性失語の特徽を有するものと考えられた。

\section{【文献】}

1) Goldstein,K.(1948). Language and language disturbances. NewYork:Grune\&Stratton. 2) Geschwind, N., Quadfase 1,F., \& Segarra,J. (1968). Isolation of the speech area.Neuropsychologia, 6, 327-340. 
2H20 自立意欲が低下した患者への精神的アプローチ〜交流分析を用いて〜

○井上友美、中原保子（取手協同病院看護科）

\section{交流分析 Ptとの信頼関係}

1.はじめに

脳外科術後患者は後遺症や、家族の受入れ がないため、長期入院を課せられる事が多 く、症状が固定化してくると看護婦も内面的 な部分を見逃しがちになり、対人関係の悪化 につながってくる。今回長期入院で自立意欲 が低下しスタッフに拒絶的態度をとり、閉鎖 的になっていく患者に、エリックバーンによ る交流分析にそって、看護婦の態度を改める 事で自立意欲がはかることができたので、こ こに報告する。

2. 方法

患者の性格を知るため、エゴグラムを取 り、プロセスレコードにより看護婦の接し方 を分析し、態度を改めていく。

3. 結果および考察

エゴグラムを取った結果、自然な姿に近い 形で振る舞う（自由な子供）の部分が少ない 事が分かった。この事は、不満を持っていて も我慢してしまい、たとえ言葉が使えてたと しても、表出する事は難しいと考えられた。 また、看護婦の態度を振り替える為プロセス レコードを取った結果、会話をしなかったの は、患者の訴えが少ない事や、看護婦に時間 的余裕がないため、家族にまかせ、処置上必 要な会話が主であり、患者に自ら話す雲囲気 を作っていなかった事に気付いた。そこには 患者からは「話しなさいと言っても、話す機 会を作ってくれていないのに」と、看護婦か らは「また、カニューレのフタをしていな
い」と、両者の間にかくれたメッセージを送 りあっていた。このように、おたがいの気持 ちのズレと、そこから生ずる相手の思いやる 態度の消失が見られた事により意欲が減退し ていることが考えられた。そこで、訪室の回 数を多くし、出来るだけ会話の時間を持ち、 治療には関係のない喜びそうな会話をした り、うまくできた時にはタッチングにより喜 びを共有するようにした。この事により両者 の間にはよい人間関係が生れ、少しづつでは あるが自分の欲求を言葉に表すようになって きた。たまたま、同じ経過をたどる同室患者 が、経口摂取できたのをきっかけに「口から 物を食べたい」「孫と話したい」との言葉が 聞かれ、経口摂取と発生練習を積極的に開始 し患者の欲求を少しでも満たすように心掛け た。最近では、ポータブル・トイレで排泄の 練習を行うなど、リハビリへの意欲も出てき ている。このように閉鎖的になった患者に対 して看護婦自身の態度を改めた事と、ス卜ロ 一クを与え続けることで、抑制していたもの が解け、意欲を引き出せたと考えられる。 夫や、母親も協力的な態度がを示すようにな り、看護婦は傾聴的な態度が身に付き、他の 患者に対しても態度が変わってきた。

\section{4. まとめ}

プロセスレコードにより看護婦の接し方を 反省し、ストロークを与える事により、心の 抑制が解け回復に繋がった。 


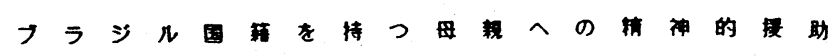

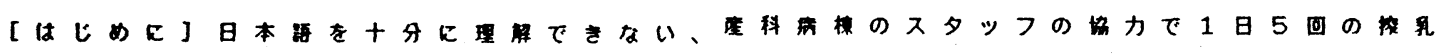

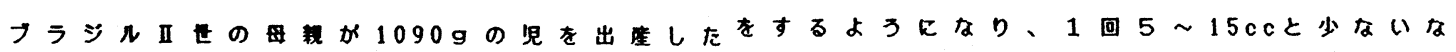

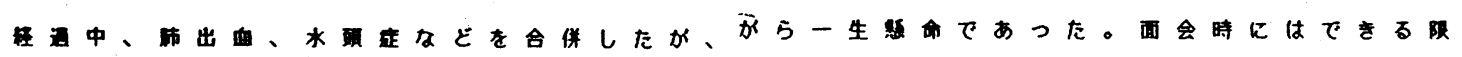

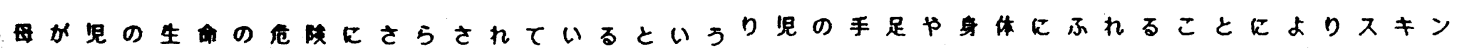

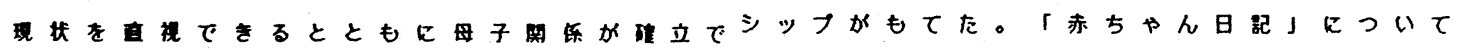

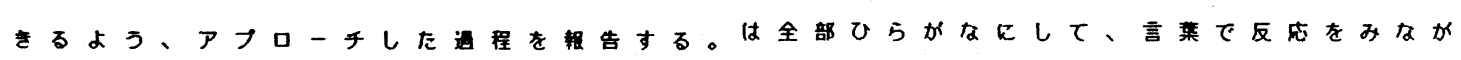

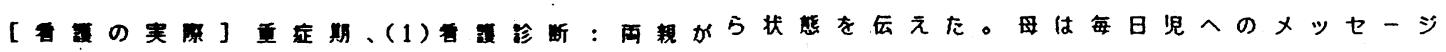

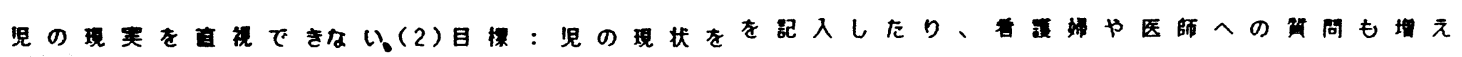

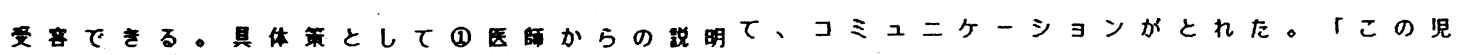

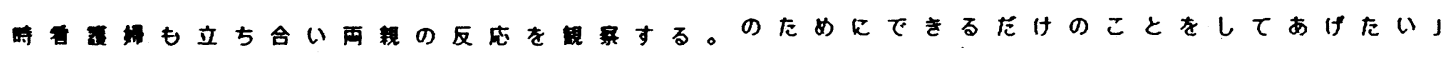

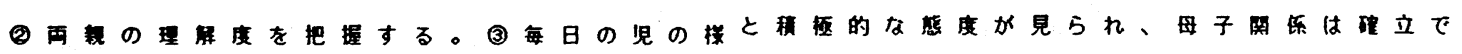
子を言集で伝える。(4)行われている治原・处きた。

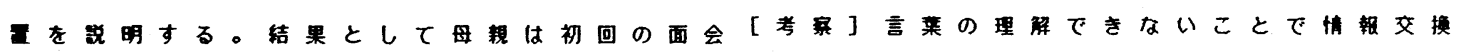
でにんな小さな晛で生命が助かるのたろうがスムースにいかす、コミュニケーションも

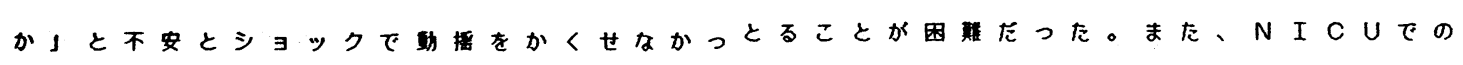

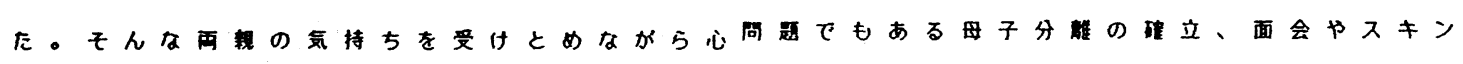

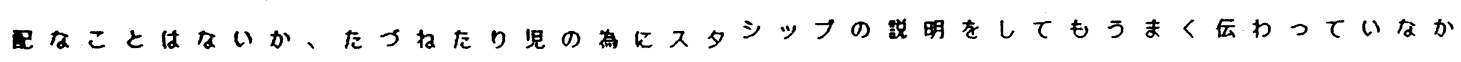

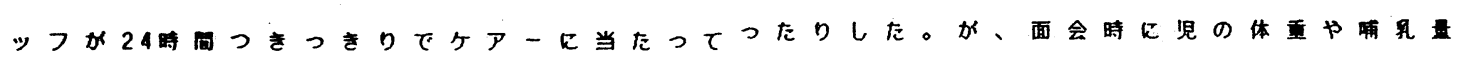
いることをわかりやすく路明することで余々などの情報を提供することによりこれらは少

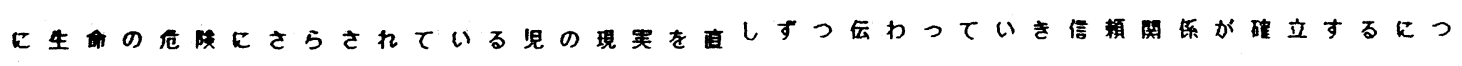

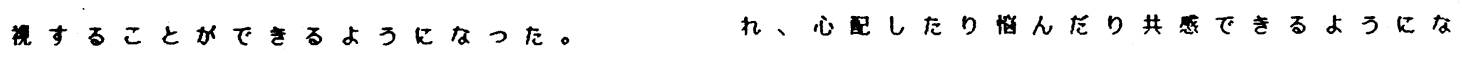

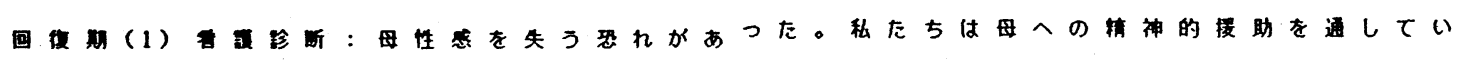

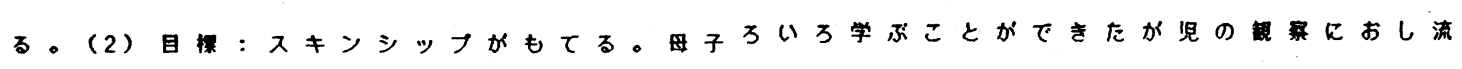

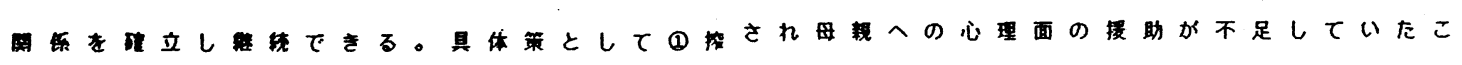

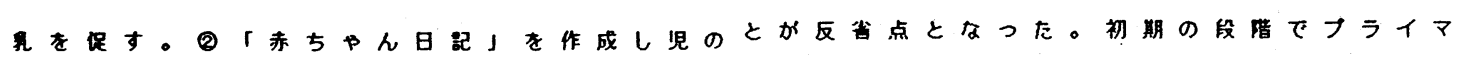

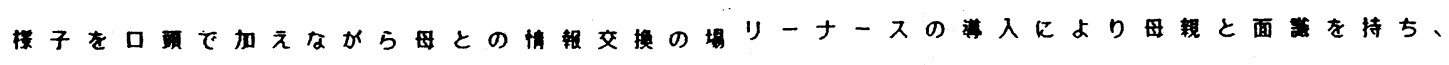

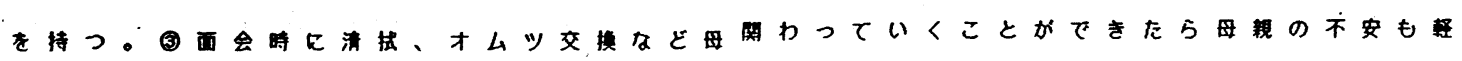

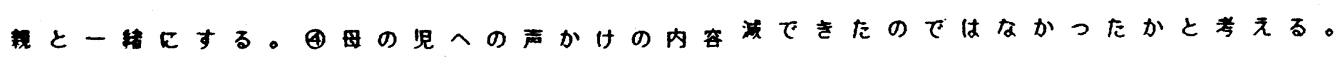

について耳を须け、面会中の样子を距する

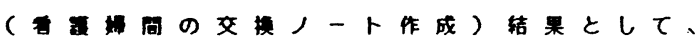




\section{$2 \mathrm{H} 22$ 患者が求めるウォーキングカンファレンスの検討 \\ — アンケート調査の分析と評価から— \\ 小諸厚生総合病院 内科病棟 \\ ○中村麻子，依田文子，金井珠美 ，山浦 翠}

調査, 分析, 評価

\section{はじめに}

医療の高度化に伴い、業務は繁雑かつ複雑 化し、処唄や検査におわれ、患者と問題点を 共有する時間が少ない。当科では、ウォー キングカンファレンス（以下 $\mathrm{W} / \mathrm{C}$ と略す）を 取り入れ一年が経過する。今回、W/Cについ て患者の考えを明らかにするため、調査研究 した。

\section{研究方法}

1) 対象 当科入院中で $W / C$ を一週間以上経 験し、口答および筆談で意志疎通がはか れる患者 103 名。有効回答数 100 名。 回収率 $97 \%$ 。

2）方法 質問用紙調査法による自記回答、 または研究者が聞き取り調査する。

\section{結果および考察}

W/Cについては、看護者が大勢で部屋を回

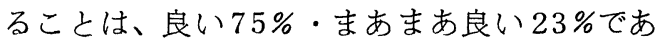
る。理由として、「患者の状態を多くの看護 者が確認・理解してくれるので安心」「隠し 事がないようでよい」などの意見が聞かれ、 W/C は良い印象を持っていると考えられる。

また、担当する看護婦の名前屯 $80 \%$ 以上の 人がほぼ理解しており、「今日は誰が来てく れるか心待ちにしている」などの声も聞かれ W/Cに関心を示している。

現在のW/Cの方法 (人数・看護婦の態度) についても、約 $90 \%$ が良いと答えている。
W/C導入にあたり心配されたプライバシー に関する調査では、同室者のことが気になら ない $49 \%$ ・あまり気にならない $24 \%$ ・少し気 になる $16 \%$ ・気になる $11 \%$ ある。また自分 の聞きたいことが聞けるかについては、聞け る $76 \%$ ・時々聞ける $12 \%$ •あまり聞けない 10 \%・聞けない $2 \%$ ある。

同室者が気になり自分の聞きたいことが聞 けないのではないかと考え検定した結果、有 意差はみられなかった。 $\left(x^{2}=8.639 \mathrm{df}=9 \mathrm{~ns}\right)$ 同室者が気になり、聞きたいことが聞けない は $6 \%$ であるが、年令・性別とあに統一性は 見られない。その他、個々の患者の疾患、性 格や社会背景などを考慮し、患者把握をしっ かり行い、プライバシー保護への配慮を怠ら ずケアしていく必要があると再確認した。

インフォームドコンセントについては、一 日の予定がわかる $48 \%$ ・゙いたいわかる $40 \%$ と高値である。内容としては、検査に関する ことが多く、前日の看護婦の説明が確実に行 われ、W/Cで再確認できていると思われる。 しかし、患者が納得できているかという点に 関しては明らかでない。

\section{おわりに}

今回の調査結果により、患者のW/Cについ ての考えを知り、良い評価を得ることができ た。今回得られた結果を、今後に生かし病棟 独自のW/Cを目指していきたい。 
$2 \mathrm{H} 23$ 患者自立度と看護・介護の関連の検討〜MD S一年の評価から F I Mスケールを用いて 愛全病院 看護部 ○吉田昭子 馬場一枝 佐藤美津子 三浦さよ

看護・介護, F I M, ケアプラン

はじめに

当院は入院医療管理 I 型の介護力強化病院 で、H 6 年よりMDS 在導入し個々のケアプ ランにより質の高い看護・介護の提供存指 している。今回、MDS導入 1 年後の患者自 立度を F I M（機能的自立度評価法）の調査 とMDSの問題領域数およびケアプランから 看護・介護を探り、調查した。

\section{I 研究目的}

F I Mの「見守り自立」や「75\%援助」の 中間レベルの患者の害態から、看護・介護を 偨る。

\section{II 研究方法}

MD S 評価表 1 年分（436 名）とF I MR よるデーターからの分析。

\section{III結果および考察}

F I Mの総合点数 (126 点満点) を90点以 上（98名）と90点以下（338 名）に区分し、 それぞれの問題領域数（18項目）・痴呆度・ 疾患別などを調查した結果、90点以下では問 題領域数は 6 〜 10 は 230 名 $(68 \%)$ と最も多 かった。18の問題領域の 1 位が「コミュニケ ーション障害」、2 位が「痴朵状態・認知障 害」であったことからコミュニケーション障 害が生じると、自分の意思や栲えを他人に伝 えることや相手の考えを理解することが難し い。

$$
\text { このことは、コミュニケーション障害と痴 }
$$
呆状態・認知障害が関連していると考えられ る。さらに、身体障害がなくても認知・コミ ユニケーション能力が低く、従って、痴呆患 者ではレベルアップに繋がり難い側面があり 心理的悪影響の排除や残存能力への働き掛け が大きなケアの役割と考えられる。このこよ 㳉、AD L，全般に関しても笑際に手がけるケ アと観察も見守りの面から介護者の精神的負 担が多く、総体的な看護・介護が高いと言え る。

おわりに

今回は、患者自立と看護・介護の関連の報 告をしたが、完全自立や完全援助の患者より 見守り自立・75\%以上援助の中間レベルの患 者の方が、看護・介護が高いことが実証出来 た。今後もさらに、質の高い看護・介護を追 求し研究していきたい。 


\section{$2 \mathrm{H} 24$ 対応困難時の患者と看護の関わりの一考察}

$$
\text { 生活力アセスメントモデルを活用した看護を行って }
$$

愛知県厚生連加茂病院 3 病棟 5 階

小野裕子 神宮みつる 吉村ちよこ 井上早苗
藤井緑 甲斐晶子 中村夏子

生活カアセスメントモデル、看護

看護とは「生命力の消耗を最小限にするよ う生活過程を整えることである。」と、薄井 坦子氏は述べている。それに沿って私達がチ ームで看護を実践する中で私達の予測に反し た事実が発生し困惑することがしばしば認め られる。このような場合には、患者及び看護 婦が共に不安定になり、看護の本来の目的を 達成するための実践へ多大な影響を与えるこ とになる。

今回、胃癌にて入院治療中の患者の看護に おいて、実践が困難となったため問題意識を 持ち、なぜそうなったのかを振り返り、看護 の目的を達成するため検討を行った。

$<$ 方法 $>$

(1) 対応困難時のプロセスレコードを検証

(2) 患者の全体像の見直し

(3) 看護婦がそれぞれに日常生活力アセスメ ントモデルを作成し検討、看護計画の立て 直し

\section{(4) 看護実践}

(5)再度プロセスレコードをとり、同時に看 護婦も日常生活力アセスメントモデルを作 成

(6) (3)(4)(5)繰り返し実践し、得られたプロ セスレコード及び日常生活力アセスメント モデルを比較、検証

以上の方法にて関わった 1 症例

$<53$ 歳、女性、胃癌、リンパ節転移>

入院時より全身倦怠感や腹満、家庭での悩 みを訴え、頻回にブザーコールする。看護婦
の言葉を全く聞き入れず、怒ったり泣いたり することが多く看護婦間では「困った患者」 と認識した。 $<$ 結果、考察 $>$

(a) 患者は高度の難聴も原因の一つとなり、 入院生活や疾患に対する不安が強いことが わかった。看護婦は患者の全体像を捉える ことができなかったため、患者の訴えばか りに関心が集中し、その場その場の言動の みに対応してしまう傾向があった。

（b）看護婦の頭の中を視覚化し共有するもの さしの一つとして日常生活力アセスメント モデルを活用した。その結果、看護婦間の 認識のずれがどこにあるのかが明確になっ た。

(c) 患者の不安な思いを看護婦が理解し、関 わりの時間を長く持てるよう配虑した。こ れまでの「困った患者」という認識から、

「何が患者をそうさせるのか」という認識 へ変わることで、患者も看護婦に対し関心 を持つように変わってきた。

(d) 日常生活力アセスメントモデルから看護 婦の対象の見つめ方が共有化されてきてい ることがわかった。

以上の如く、他の胃癌患者を含めて検討し、 患者自身の個別性、問題点を捉え看護婦間の 認識のズレを縮めることで患者との関わりに 変化がみられたので症例呈示を含めて報告す る。 


\section{$2 \mathrm{H} 25$ 糖尿病継続指導への取り組みと治療継続上の問題点の検討}

$\bigcirc$ 和田芳美、中元美恵

（厚生連廣島総合病院・西 2 階病棟）

\section{糖尿病、継続指導}

当院では、昭和 61 年より糖尿病教育入院 の開始に伴い、教育入院看護展開システムを 構築、発展させてきた。しかし、退院後の患 者への継続的な援助・指導や、私共の教育効 果を長期的に評価する外来指導システムを持 っていなかったため、教育のやりっぱなしの 状態であった。

外来における継続指導には、指導スタッ フ・場所等の物理的条件、及び外来患者教育 の看護展開システムのあり方が課題であっ た。そこで、それらを少しずつ整え、平成 6 年 2 月より、月 3 日試験的に外来指導を開始 することができた。教育入院病棟の教育担当 ナース 2 名が交代で外来指導室へ入り、同年 5 月より月 10 日に回数を増やし現在に至っ ている。

平成 7 年 4 月末現在、外来指導人数は 33 8 名、延指導件数は 460 件である。当初外 来指導の目的としていた継続的援助ならびに 教育効果の評価に加えて、外来通院患者の初
診時よりの適切な援助、また、入院が必要と 診断されても社会的事情で入院困難な患者の きめ細かい援助が可能となった。

外来指導者 338 名中教育入院経験のない 外来通院者は65名 (19.2\%) で、ほとんよ゙ は教育入院後の継続指導である。教育入院後 の定期的教育効果の評価のため、外来指導を 行うケースもあるが、半数以上がコントロー ル不良や、治療継続に支障をきたすような何 らかの問題点を抱えた患者である。

退院後各自の生活に戻った患者の抱える問 題の主なものは、男性では仕事上の接待によ る飲食、習慣性の飲酒などで、女性ではスト レス解消の多食などであった。さらに、これ らの問題点之治療継続の必要性の認識との間 に大きな葛藤をも併せ持ち、さまざまな苦悩 のあることがわかった。今回、外来指導室で 面接方式で聞き取ったこれらの問題点の調查 結果と今後の課題について述べる。

\section{【看護指導システム】}

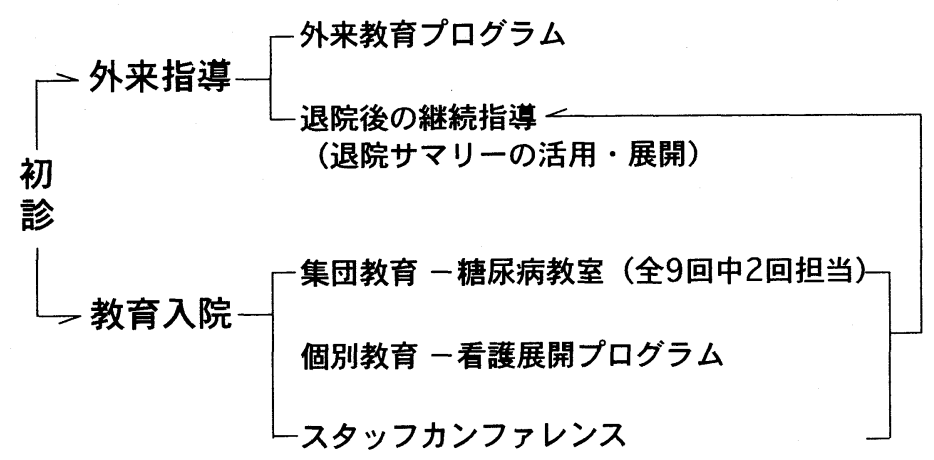


2H26透析患者の高 P 血症に関する病識の調査研究

金沢西病院透析センター

○奥山三枝子菊地 誠 奥田肇

佐藤 美智子

\section{(1)透析患者 (2)高 P 血症 (3)病識}

I 。透析患者に於て食事からのP 掑取過剩は、

表1リン(P)についての供問項目

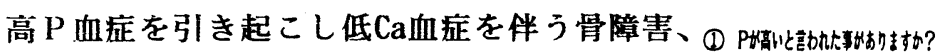

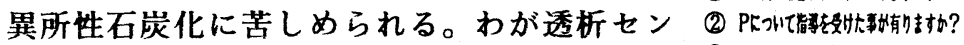

ターでも年間 $60 \%$ が、高P血症を示す。食 事や内服の指導を行ってもなかなか改善がみ られない。そこで、高P血症を引き起こす誘 因を考えてみた。自己コントロールの為、低 P 食品をすすめるが、嗜好及び経済的な問題 がある。そこで、Pの意識調查から年龄や透 析年数を分析し、食事指導への指標を考察し た。

II. 研究方法

1. 調查期間 平成 5 年 7 月 平成 6 年 6 月

2. 調查対象 当センター高P血应患者 28 名

3. 調査方法 過去 1 年間の平均血清值 $5.5 \mathrm{mg} / d \ell$ 以上者を抽出後、透析年数を調査。さらに

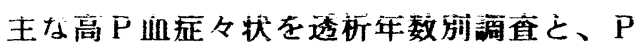
に関する意識を聞き取り調查で行なう。

III. 結果
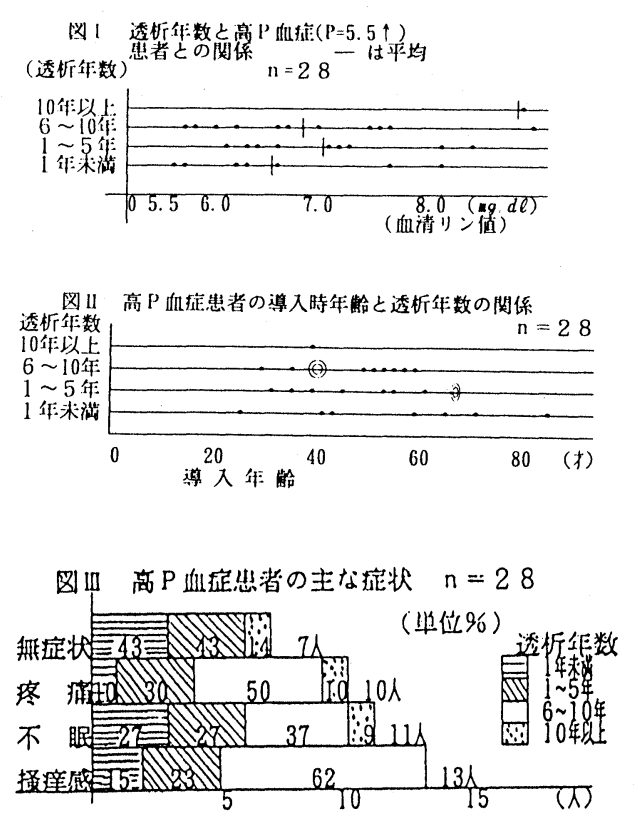

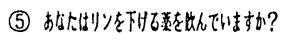

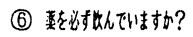

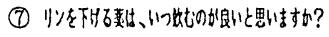

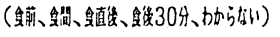

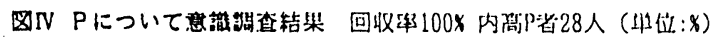

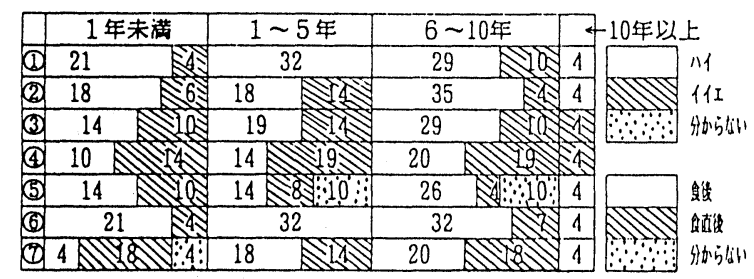

IV. 考察

図 I より透析年数に関係なく高値を示す。 近年高齢者の導入者が多く、理解度の之しさ と長年の食習慣から容易に受けとめれず高 $P$ 尚症に至ると考えられる。又、透析年数が長 期で導入年龄が若い患者は、P值にバラつき があり、理解できるも慣れからの気持のゆる みが、高P血症を起こす要因と考えられる。

図而の症状別からは、透析年数が長期に伴 ない高P血庭々状を示す。症状が出始めると その莚状に悩まされ、Pに関心を示すように なり、検查値・内服薬について自覚する。し かし長期の生活習慣から抜け出すには、努力 を必要とし、食生活の改善には、至らない。

意識調査より「指導を受けていない」の返 答は、他施設の導入者が多く、指導内容の確 認が必要である。又、指導を受けたにも高 $P$ 血应を示す背景を調べた所、「わかっている がつい食べてしまう」「蛋白質を制限すると Ht值が下がり体調が悪くなる」などと、故意 的に掑取する傾向がある。これらから、食品 の種類と量を踏まえた指導が重要である。 V. 参考文献

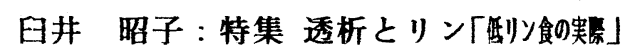

監床透析 (1991) $\mathrm{v} 01.17 \mathrm{~N}$ o. 11

日本メディカルセンター 
$2 \mathrm{H} 27$ 視覚障害と血液透析とのダブルハンディをもつ患者との関わり

擪生“連”高阔病院（透析窒）
○川崎孝夫中江. 幸子若杉珨子
福島敦子 林和美

はじかに

透析療法は、腎不全を救命できる治䝤法で はあるが、この治療法でしか自己の生命を救 えないという現状を受け入れられる患者は少 ない。また、「視力を失う」ということは人 生において最も悲涌な出来事であり、「見え ない」=「何も出来ない」という認識をもち やすい。春木らは、「血液透析」と「視力障 菁」との複合障害は絶望感、意欲低下へとつ ながり、はては人生に対する拒否的感情を有 するこしがあると述べている。当透析室にお いても同様のハンディを持つ患者がおり、嬮 计的で闘病意欲の見受けら扎ない一面が何え た。透析を受け入れられず、厭他的な患者が 少しでも明るい気持ちで意欲的に生きられる ように、プロセスレコードをとりながら㗢き かけた結果、改めて看護の姿勢を見直すこと ができたので報告する。

1 研究目的、方法

厭甘的で透析受け入れ困難の原因を探り、 患者が意欲的ではりのある生活が送れるよう 援助方法を考えるため、透析中に、ベットサ イドで全会話を録音し、プロセスレコードを 上り、分析する。

2 結果

プロセスレコード結果はスライド参照

\section{3 怒祭}

疾患の理解不足と、日が見えないという八 ンディのため毗世的で䦥病意欲がみられない、 睍状を受け入れることが出来ないと判断し、
精神的アプローチを試してきたが、プロセス レコードの分析結果として透析導入前の医師 ๖のコミュニケーション不足が大きなウエイ トを示していることが明かとなり、患者個々 ににあった導入前の看護婦アプローチの仕方、 受け持ち制を導入する必要があると考える。 また「嫌なものは嫌」「痛いものは痛い」の であって、人間のもつ好き嫌いの感情そのも のを認め、適確な対応をする。逢沢は「いつ か治れば」「いつか日がみえれば」と言う希 望を持ち続けることは自分をありのまま肯定 的に受け人れる「受容」亡其存するものてあ ると述べているように、安易な慰めはかえっ て反発心を招く之考える。一生透析と共に生 きていかねばならない患者にとって、自分を 理解してくれる看謢婦がひとりでも存在する ことは心の支えとなり同じ透析患者同志仲間 意識を持たせるようなかかわり方をしたこと により、自ら前向きに転換するきっかけとな った。私達は常に「聴く」という姿勢と、医 㩆之の間に江ち、患者と共に歩む、支援する という態度を忘れてはならないと考える。

$$
\begin{aligned}
& 4 \text { まとめ } \\
& \text { スライド参照 }
\end{aligned}
$$

\section{《参洘文献》}

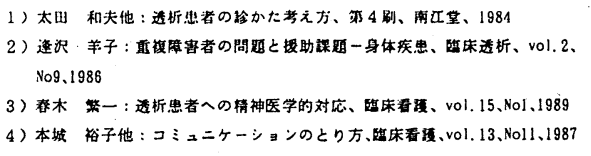

《引用文献》

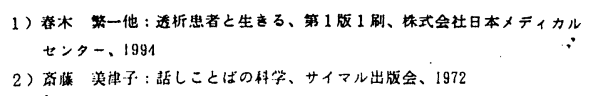


$2 \mathrm{H} 28$ 透析導入における患者指導一患者指導マニュアルの作成一

J A 岐阜厚生連中漂病院 5 階病棟

○可児佳緒里市川明美浅野涼子福田厚子
継続的な患者指導

慢性疢患の増加に伴い、長期間の療養を要 する人が多くなり、これら患者の抱える健康 問題やそれに対する医療について、患者や家 族の関心が高まってきた。十分な知識、情報 を提供し、同意を得た上で病気の治療、さら には健康の増進という目標に向かって共に努 カするという、インフォームド・コンセント の理念に基づき、適切なインフォーメーショ ンを、効果的に与える患者教育が重要になっ ている。

当筑棟においては、慢性腎不全患者が多く 入院し、透析導入における指導は、専ら経験 のある看護媂に委ねられ、指導回数、内容に も個人差があり統一性がなかった。また、患 者側の理解度や人生観、価值観の違いからも 指導が生かされない事が多くあった。これら の問題意識から、統一した指導と継続的な看 護を行う為に以下の方法を試みた。 1 , 透析 指導に関する資料収集と勉強会。 2 , 看護婦 意識調查の実施。 3 , 患者アンケート（面接 調查)。123の結果から、患者指導マニュ アルの検討を行い、1) 透析導入における患者 指導パンフレット、2) 患者の理解度を把握す る為のチェックリスト、3)患者指導用パンフ レットに沿った看護婦用指導マニュアル。4) 透析導入における指導計画マニュアルを作成 し、受け持ち看護妢による個別指導に重点を 置き、患者のニードや関心度に合致した場合 はより指導の有効性が高いと考光実践した。 また看護婦は、患者についてよく知り、より
よい人間関倸を築くよう努力したが、残念な がら今回の研究においては、指導の評価まで には至らなかった。患者の自立に向け $1 つ の$ 指針となるマニュアルができたが、今後の指 導は、病棟看護婦のみにとどまらず、透析ス タッフらとも協力し指導していかなければな らない。患者個々に関係する医療スタッフの 継続的なケアが、患者湖々のQOLにつなが る事を期待したい。浜口らは、「透析療法を 継続していく上で、自己管理はあくまでも自 分自身の責任であることを自覚させることに あるが、その過程においてスタッフは責任を おしつけるのではなく、受容的態度、患者の 内面を引き出させ、ともに考光る姿勢が要求 される」と述べており、指導だけにとらわれ ず、日常のケアの中から、患者の精神的問題 をとらえ、ニーズにあった看護ができるよう 自己研鑍しなければならない。また透析療法 を行なうには、家族の多大な協力が患者の社 会復帰に大きな影響を及ぼす為、家族を含め たケアや指導も重要であり、今後課題として 取り組んでゆきたい。 
札幌厚生病院外来部門 ○扇谷五十子花田祐子 同 消化器科病棟酒井紀美代蝦名律子

同 医 療相談室服部雅之

\section{クローン病相談室体験交流 · 疾患の理解 チーム医療}

〔目的]炎症性腸疾患・Wる様だ。食事指導、 クローン病は、若年者調理指導が参考になり 層に多く進路や学業生退院後自分でも調理し 活の継続、就職等支障てみたい。又、体験交 を来す例も少なくない。流会では、苦しんでい 種々の問題に対処する

ため 6 年 3 月か らク口 るのは自分一人ではな

一ン病相談室を開設、

い。胸のうちを出す事 チーム医療を目ざし運 が出来た。毎回参加す 営にあたっている。今 ることで不安が軽減し たとしている。ソーシ 回相談室门実態把握、 課題を明確にし、今 後 の相談室のをりり方を検

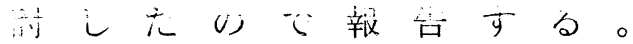

[方法] 相談室参加者 へのアンケート、患者 家族の年代別、月別参 加等の調查。

[結果]参加者（患者） の年代 - 性別は、10才 代 $16 \%$ 、 20 才代 $51 \%$ 、 30 才代 $21 \%$ 、男 46 名、 女 11 名である。通算 12 回 開 催 し 参 加 総 数 315 名で患者 175 名 $56 \%$ 、 家 族 131 名 $42 \%$ 、父 親 の参加も目立つ。内容 では講演、食事指導、 交流会を主とし、病気 の全体理 解 や合併症に $つ い て$ 知識が得られて

種々の相談につながる ケースもある。

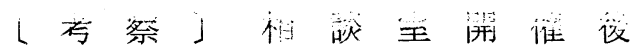
毎回スタッン会議を行 っているが、運営内容 について 検討、更に当 事者の参加を含め計 画 評価していきたい。医 師の講演は毎回組入れ、 新参加者へ対応したい。 体験交流、栄養士によ る食事指等導を通し、 多様な二ーズに答える よう考えたい。

[まとめ]チーム医療 により、患者家族の $\mathrm{Q}$ O L を考える相談室で あるよう心がけたい。 
$2 \mathrm{H} 30$ 喘息教室開催において保母の介入とその役割

仲澤志浦、猪瀬留美子

総合病院土浦協同病院小览科病棟

喘息教室鍜練療法

【はじめに】当病院では、喘息患児と家族 が疾患について正しい知識を習得できるよう に、定期的に喘息教室を開催してきた。従来 は、医師や栄養士の専門的な講義を中心的に 行いその効果を上げてきたが、今回は更に保 母の介入により幼稚園教育の経験を生かした 活動を取り入れて内容の改善を試みた。併せ て家庭です鍛練療法が持続して行われている かどうかす調查した。その成果について記述 調查の意見を参考に検討したので活動内容も 含めて報告する。

【対象及び方法】対象は、平成 6 年 6 月〜 平成 7 年 2 月までの期間に開催された 4 回の 喘息教室参加者総数 102 名のうち保護者 54 名 である。方法は、毎回終了時に記述用紙を配 布し、その場で記入してあらい回収した。回 収率は、全回とも100\%であった。

活動内容今回新たに取り入れた活動は、1. 「音楽療法のばし歌」歌唱を利用した呼 吸訓練法で 1 フレーズの最後の音を、できる だけ長く伸ばして歌う腹式呼吸の自然誘導で ある。2．「オリジナル喘息体操」遊戯を 取り入れたリズムのある全身体操で、素早い 吸気の腹式呼吸と呼吸筋の鍛練療法である。

\section{3.「喘息教室新聞の作成」毎回終了後、} 模造紙に活動内容之記述調查の結果報告、次 回予告を兼ねて作成し小児科病棟、外来に掲 示したあのである。

【結果及び考察】音楽療法では、キーボー ドを使用し、「ドレミのうた」を選曲したこ
とで患児の興味も深まり、回りの様子を伺い ながら行えた。喘息体操では、杪ジ师ィーを を生かし遊戯を取り入れたことで、体力的に す無理がなく伸び伸びと活動できた。体を動 かす事が苦手な患児す喜んで参加でき効果的 であった。又、これらの活動を、親子で参加 できた喜びす大きかった。記述調查結果によ ると、「楽しくて覚えやすい」「毎回取り入 れて指導してほしい」という意見が得られ、 参加率增加にすつながった。しかし、家庭で の鍛練療法の持続性については、良い結果が 得られなかった。その点については、家族の 励ましが患児の意欲に大きく影響するものと 思われ、家族に鍛練療法の持つ意味を良く理 解してあらうことが大切であると考えられた。 今後は、夏休み期間中に、週一度の特別教室 あ計画している。喘息教室新聞の作成、掲示 については、豊富な色使いと、写真を添付し たことでょり良い反響があり「興味深く見た」 「自分が写っている写真を見ると嬉しくなる」 などの意見が得られた。今後も充実した内容 の提供を考慮し、発行できるよう工夫をする。 【結論】喘息教室における保母の役割は、 患児が喜んで参加できるように誘導し、参加 率の增加を図ることである。そして、家庭で あ鍛練療法を維持することが発作の予防と軽 減につながることを認識させることである。 今後む、喘息疾患を持ち悩む患児や家族との 信頼を深め、積極的に心身の鍛練ができるよ う配虑をしていきたいと考えている。 
○佐藤法子、宮本留美子、加藤美津、栗木智恵子

(取手協同病院看護科)

患児をもつ母親

【はじめに】小児科の入院患児においてその 疾患・年齢および家庭環境は様々である。当 小児科病棟では患児の精神的ケアーなどの理 由から母親が付き添う場合がある。今回、私 たちは患児の付き添いという形で病院生活を 送った母親の不安・不満を調査し、今後の看 護活動を円滑にするために検討した。

【方法および対象】方法 : 無記名のアンケー 卜方式、項目 : (1)患児の病気・病状(2)病院 · 病室の設備(3)病院食(4)入院中の他の家族(5)退 院後の生活、調査期間：1994年 4 月〜 6 月、 アンケート配布数：100部（回収率：98\%）

【結果】項目別回答内容を以下に記す。

(1)患児の病気 · 病状

(1)に関してのみ記述式としたため回答があま り得られずパーセントに表せなかった。 *疾患の軽快が短期に得られない＊病状そ のものへの不安 * 将来的な症状への不安 (2)病院・病室の設備 *病室への不満 $(49 \%) \cdots$ …狭い（37\%）照明 (12\%) * *ベッドへの不満（50\%）…狭い * 輸液ポンプヘの不安 $(64 \%)$ …不自由 (3)病院食 *おやつがワンパターン (37\%) *内容が 悪い (37\%) *食器が悪い $(24 \%) \quad *$ 彩 りが悪い $(24 \%) \quad *$ 年齢不相応 $(22 \%)$

(4)入院中の他の家族

* 食事を作れない（30\%）＊患児の兄弟の 世話ができない $(26 \%) ＊$ 自分の仕事が心 配 (15\%)）（入院費など経済状況（18\%）
他部署への働き掛け

(5)退院後の生活

*入浴・食事 $(30 \%) *$ 内服薬について (25\%) *再来の条件 $(10 \%)$

【考察】以上のアンケート調査から私たち は、対処できる問題から検討した。(1)の患児 の病気病状については、気安く私達に不満等 を話せるよう受け持ち制を実施した。また、 入院時に医師に十分な話し合いをするよう依 頼した。(2)の病院・病室の設備については、 病床数を削減し、病室にゅとりを持たせた。 (3)病院食については、栄養科と相談し手作り で且つ、患児が見て喜ぶものとした。(4)の入 院中の他の家族については、面会にくる父親 に私達のほうからも積極的に様々な協力を依 頼するなどして母親を支える努力をすること にした。(5)の退院後の生活については、入院 中に食事指導をし、内服に関しては薬剤師に よる細やかな説明で納得が得られている。以 上の今回の検討から、私達は改めて患児をも つ母親に対する十分な話し合いの重要性を再 認識するとともに他部署の業務に対する働き かけの必要性を痛感した。今後、これらの結 果を看護業務に生かしたい。

【おわりに】アンケート方式により入院患児 に付き添う母親の不安・不満について検討し た。様々な回答が得られたが、今後とも私達 の立場からそれらを積極的に引き出し、入院 生活を精神的にも安心して送れるように、ま た安心して退院ができるように外来と協力し あい、より良い看護活動をしていきたい。 
2H32 男子学生に母性看護実習を実施して（アンケート調査より）

\section{川上久美子林幸子小崎鄉子星美智}

(長岡中央病院。中央看護専門学校)

母性看護実習、男子学生、アンケート調査

\section{I .はしめに}

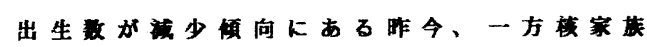
化现象もさらに進行している。䚀にとって 一番身近な存在で在る父期の育奣加山心䫂 である。そのような時代に沿うかのように平 成 2 年度に看設数育カリキュラムが政新され 男女の区别なく性看鿁実署が必須科目とな り当校上おいても今回初めて男子学生の悗 実署を行った。その振り返りとして男子学生

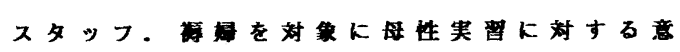
誡を知り実習指傋に役立てたいと考えアンケ

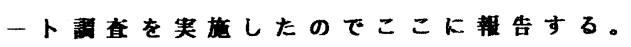

II. 語直対象

1. 男子学生 1 学科 3 年生 2 名 ( 20 拿)

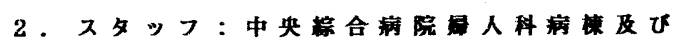

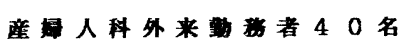

3.得国：中央綡合病院人科㾝䅦で平成6 年 5 月 16 日施同 6 月 16 日までに分耧に

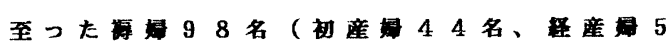
4 名)

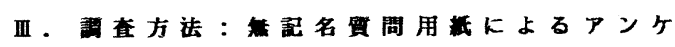

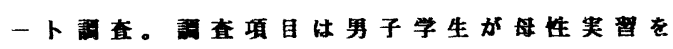
行うことの意見、最想、实習中のこたかり、 実習项目についての希等である。

V. 結果

1. 男子学生：学ひたついて「出痤とはとて

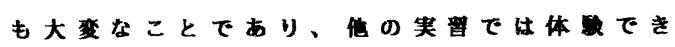
ないことを学んた」困っことは「拒否された 」「とこまでケアしていいのか?」うれしか つた事「家庭颜閣で子供が元短だった」「2
事高け持与、元氛に退完された」要望は「 病梀スタッフと実罾の打ち合わせを密に」「 男女の勋なく接して䊏しい」等たった。

2.スタッフ：男子学生の実習の必要性あり 25 名 $(67 \%)$ 、不必要 11 名 $(29 \%)$ 必要と思う理由は「新しい生命の誰生と看誫 の役㲅を知って族しい」「看識を行うのにあ たりとんな科でも女性は存在する」不心慗と 思う理由「実習したことのメリットがない」 「患者及びタッフに不快、不安を与えやす い」等であつた。

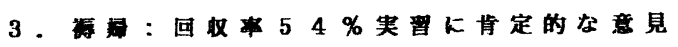
「これからの時代大いに䩀成」「蕾広い体路 を生かして実力を眝えてほしい」等であった

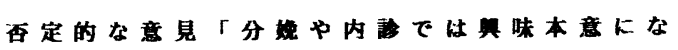
るので岋」「夫や医的以外の男性に見られた くない」等たった。

V. 孝察

母性实習は、自分の存在を䐂誡し、人とし

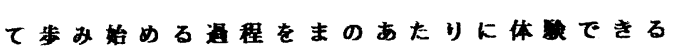
夹習である。看亜士の育成においても久かす 事が出来ない実罾であると考える。スタッフ が、男子学生の性実習を有意美でないと判

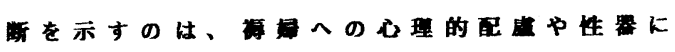

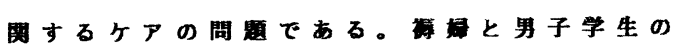

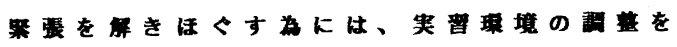
スタッフと般員間で共通理解し、実習内容・ 方法が局の貝担とならない機にしたい。更

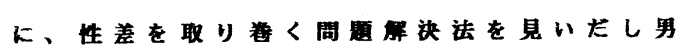
子学生にとって有意意な実習としたい。 
2H33 これからの外来看護を考える 一オストメイトのセルフケアーを通してー

○鈴木 友枝、片岡 妙子、成島 泰子（取手協同病院看護科）

\section{外来業務の見直し}

\section{1.はじめに}

外来において、従来看護婦の役割としては 診察、検査、治療の補助的業務や雑用に追わ れ、患者を 1 集団としてとられて、数をこな すこと、待時間を少なくすることに試行錯誤 していたように思われる。そこで外来看護婦 業務についての実態調査を行い、私たちが抱 えている現状の問題を明らかにした。さらに 外科外来の 1 事例を通し外来看護について再 認識する機会を得たのでここに報告する。

\section{2 . 調查方法}

対象：外来看護婦 35 名

方法 : アンケートによる実態調査

\section{3 . 結果}

日常業務の中で問題だと思っていることを 15項目のうち 3 つ選択してもらった。(1)患者 の話しを聞く余裕がない、(2)患者指導や生活 指導ができない、(3)待合室まで目が行き届か ない、この 3 点が上位を含めた。本音と立前 の峻別ができていない現状の中で看護婦は、 問題意識を持ち、日々の患者ケアーに生かそ うと努力がうかがえる。そこで 1 事例を紹介 する。

\section{4. 看護展開及び考察}

アンケート及び事例を通し次のような外来 看護を考えてみた。

(1) 看護婦のアシスタント的役割の医療秘 書や他の医療チームとの協力の基に業務の役 割分担をすることにより、限られた時間の中 で、患者の来院日に合わせ時間を作ること等
オストメイトの退院後のケアー

ができた。

（2）外来看護には通院する患者の生活全般 についてのマネージメントが大きな役割とな る。本事例は術前よりストーマが受容できず リハビリに時間を要した。退院後も一人暮ら しのため不安は多く、精神的にも、情緒的に も不安定な状態が予測され、そのため、プラ イマリーケアーを実施した。看護チームは、 患者の抱えている問題について情報を交換 し、共有できるよう外来においても看護過程 を記録に残す必要がある。

(3) 経済的側面において、市の福祉課と連 絡をとり、障害者福祉制度に基づいた手続き をすすめ、手帳公布を受けた。これからは院 内に限定されるのではなく、地域の医療機関 との連携を保つことが必要とされ、看護婦は 厚生行政について常に新しい情報をキャッチ し、社会福祉サービスを提供できるような姿 勢が必要である。そこで本院では、オストメ イトの会「コスモスの会」が設置されており ストーマ外来と平行し、装具の紹介や、勉強 会を含め親睦を図っている。本事例の場合も 会に参加し他のオストメイトと楽しく会話し 有意義な時間を持つことができた。

\section{5.まとめ}

日常業務の中で忙しさに流されず、個々の 看護婦が問題意識を持つことにより、外来看 護とはどうあるべきか問い続けていきたい。 
2H34 リハビリ病棟における脳卒中評価法（FIM,SIAS)の経験一第 1 報一

由利組合総合病院リハビリ病棟 ○福岡幸記,佐藤洋子,熊谷京子, 前川真理子, 細谷兼義,三浦ミヤ子,佐々木光代, 伊東たづ子, 工藤義教, 中川裕子, 山浅勉, 平出健夫, 堀井ナ才子, 朝倉健一, 青柳耐佐

脳卒中リハピリ、FIM、SIAS

【はじめに】平成 6 年11月に由利組合総合病 院が新築移転し、新しくリハビリ病棟が開設 されたのを機に、脳卒中患者におけるリハビ リを進める上で必要なスタッフの共同認識を もつために、新しい脳卒中の評価法を採用し、 その意義および問題点を険討した。

【対象と方法】脳卒中患者でリハビリ病棟へ 転棟してきた患者を对象とした。男性23例、 女性 11 例の計 34 例で平均年齢は64.8才(41才 〜81才) で、疾患は脳出血16例、脳梗塞18例、 発症から転棟してくるまでの期間は、平均 25.4日であった。評価法は、国際的に普及し つつあるFunctional Independence Measure: FIM (機能的自立度評価法) と、慶応大学医学 部リハビリ科で開発したStroke Impairment Assessment Set:SIAS(脳卒中機能障害評価七 ット)を用い、リハビリ病棟入院時、1カ月後、 2カ月後および退院時に評価をした。評価は、 FIMは看護婦が、SIASは主としてPTが行った。

FIMは、ADLの各18項目を完全自立から全介 助までを7段階に分けて得点を与えるもので、 運動項目に関しては従来のBarthel indexを 基準としている.さらに、コミュニケーショ ンや社会的認知も評価の対象として加わって

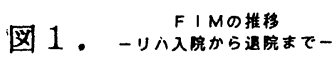

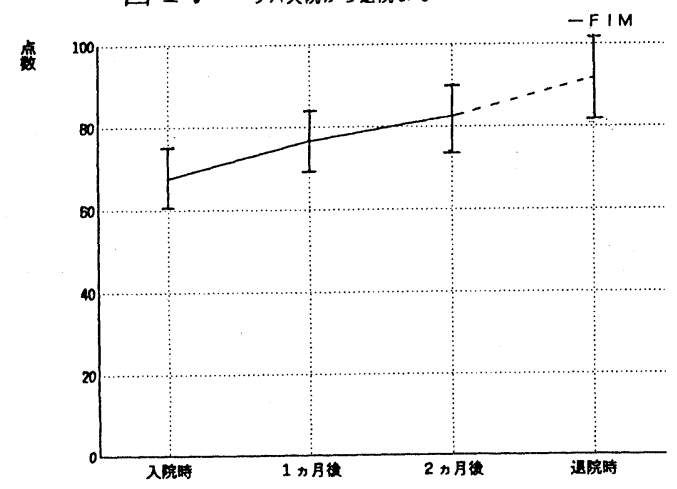

いるのが大きな特幑である。一方、SIASは上 下肢の運動機能、筋㗨張、感覚機能、関節可 動域、疼痛、体幹バランス、視空間認知、言 語機能、健側肢機能の10大項目について評価 する。個々の項目は単一手技で評価し、0-5 点あるいは0-3点を与えるものである。

【結 果】入院時の平均点数は、FIM67.5(18 -125)点、SIAS42.4(13-68)点で、出血か梗塞 かによる差はなかった。FIMにおける1カ月後、 2 力月後と退院時の平均得点は、それぞれ、 76.5 点、82.4点、91.6点で、ADLの向上を客 観的に数值として把握することができた（図 1)。また、SIASは 2 回目の得点は平均 43.5 点であり、入院時に比較して若干の改善が確 認された。さらに、SIASをレーダーチャート にして比較した場合、拡大の著しい症例（図 2) と、ほとんど変わらない症例があった。 【考察】リハビリを行う上で、客䂓的な ADL評価法を用いると、共通の認識と目標を もってあたることができ、看護目標もたてや すくなった。リハビリスタッフとも同じ観点 からみることができ、チームリハビリを進め る基準となった。細かい点で、まだ評価に不 慣れな点が多いが、今後、症例を重ねていき、 質の高いリハビリ看護をめざしたい。 図2. Stroke Impairment Assessment Set (SIAS) 定例：T.A. 56才,男

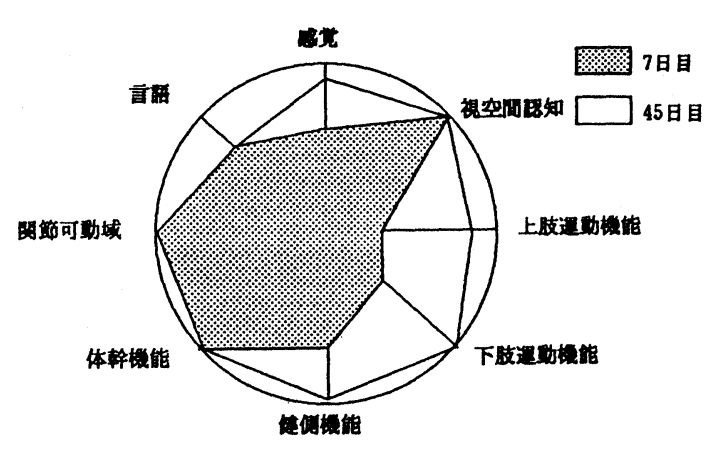


○安藤真由美 高橋妃佐美
小谷弥生 大坪真夕
岡林 芳

前田記美恵

付添い廃止・スタッフの増員 ・看護の充実

\section{1・はじめに}

当院は、北海道のへそと呼ばれる富良野市 の南部にあたり、外来診療圈の人口は約 5900 人の農業を主幹とした地域で訪問診療に力を 入れ活動している。

病棟32床、外来診療三診体制に加え、訪問 診療、訪問看護患者が 145 人に増加し、住民 のニーズに合わせた活動のためにマンパワー の確保は不可欠と考えていた。加えて、法令 改正による付添い看護廃止についても、スタ ッフの増員の必要性が高まった。これらの事 より大幅な看護体制の改革を行ったので、現 状と課題について報告する。

\section{2 ・改正の実際}

○過去と現在の比较

\begin{tabular}{|c|c|c|}
\hline & 平 成 6 年 度 & 平成 7 年 5 月末現在 \\
\hline 看讙婦数 & 正看 2名、准看 8名 & 正看 5名、准看 10 名 \\
\hline 看讙助手数 & 平成 $7 \cdot 3 \cdot 1 \sim 3$ 名配属 & 3 名 \\
\hline 勤務体制 & $\begin{array}{l}\text { 1名旦当直 } 3-4 \text { 回 } / \text { 月 } \\
\text { (1宣待機) }\end{array}$ & 2名夜動 4-5回／月 \\
\hline 看㜔料金 & その他 & B 加算 \\
\hline 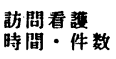 & $\begin{array}{l}14: 00-16: 45 \text { 月 金 } \\
\text { 平均 } 2-3 \text { 件 } / \text { 日 }\end{array}$ & $\begin{array}{l}8: 30-16: 45 \text { 平均 } 5-6 \text { 件 } / \text { 旦 } \\
\text { 舟 }\end{array}$ \\
\hline カンファレンス & 毎週水曜日 & 每日の定例化 \\
\hline
\end{tabular}

*付添いの廃止は、入院患者の家族にとって 介護・経済的負担の減少となっている。 *複数の看護婦の判断で、入院・外来・訪問 看護の対応が迅速に行えるようになった。 *看護助手と共に、日常生活援助を行うこと で情報の幅が広がっている。 *訪問看護の件数の増加之活動内容の充実。

\section{3 ・考察}

基準看護を導入することで、患者負担の付 添いを必要としなくなったことは、家族の負 担が少なくなった。また、患者自身「家族に 迷惑をかけなくてすむ」等の声も聞かれ、良 好な家族関係が保たれることにつながってい る。しかし、逆に家族と患者が疎遠になり、 スムーズに在宅へ戻る事ができないケースも 出てくると考えられる。

また、スタッフの増加に伴い、ベッドサイ ドに行く回数、時間が増え、今まで以上に患 者と深く接する事ができ、看護の充実につな がっている。

訪問看護については、退院後訪問が早い時 期に行けること、定期訪問の回数が増えるこ となどから、在宅での問題点が早期に見極め られ、対応出来るようになっている。このこ とが、地域住民の支援体制の充実につながっ ていると考えられる。

\section{4 ・まとめ}

新看護体制を図ってから期間が短く、評価 の出来ない事項が多いが、スタッフの増加に 伴う改善点はとても幅広いものだと考える。

今後は、スタッフ間の意思疎通もスムーズ にする点や、患者や家族により近づいた看護 の提供のために、カンファレンスの充実およ び記録の方法など改善してゆくことで、より 一層の看護のレベルアップを目指して行きた い。 